\title{
Novellas for Diverting Jewish Urban Businessmen or Channels of Priestly Knowledge: Redefining Judean Short Stories of Hellenistic Times
}

\author{
SYLVIE HONIGMAN \\ Tel Aviv University
}

\section{Introduction}

Virtually all textbooks on biblical literature include a chapter devoted to a category of works variously dubbed 'Stories of Biblical and Early Post-Biblical Times', 'Narrative Literature', and the like. ${ }^{1}$ Under these assorted labels, modern scholars have gathered texts included either in the Hebrew Bible or in the Septuagint (and sometimes free-standing texts) that tell a story involving unknown or marginal figures from the past — including women - in ways that are perceived as being 'entertaining', and which for this reason are widely held to originate in oral, popular literature. Given these loose common denominators, the lists of works assigned to this category vary considerably from one modern survey to another, and scholars typically lump together works belonging to a variety of literary genres composed in diverse languages (Hebrew, Aramaic, or Greek) at supposedly different times (Persian, Hellenistic, or imperial), and in different places (Judea, Egypt, and Persia/Mesopotamia). To complicate things further, the date, placeand even the language of composition - of most of these works are readily disputed. Moreover, some of the texts considered are embedded in wider works, such as the 'tales' in MT Daniel 1-6 and the Story of the Three Guards slotted into LXX 1 Esdras 3,1-5,6.

The core list of these texts includes Esther, Daniel 1-6, Judith, and Tobit. As 'court tales' (or 'legends') scholars regularly add the aforementioned Story of the Three Guards in 1 Esdras, the Joseph story in Gen 37,2-48,22, and the Story of Ahikar (which was not Jewish but is alluded to in Tobit); as 'historical fictions'

\footnotetext{
${ }^{1}$ See, for instance, Nickelsburg 1984; Doran 1986; and the selection of works in Wills 2002.
} 
the Letter of Aristeas, 2 Maccabees, 3 Maccabees, the Tobiad Romance and Royal Family in Adiabene (Josephus, $A J$ 12,154-236 and 20,17-96); as 'novellas' Joseph and Aseneth; three 'Testament' texts (of Abraham, Joseph, and Job) are sometimes included in this category and hence separated from the rest of the Testament literature, usually enjoying a chapter of their own in the said textbooks. ${ }^{2}$

In the course of various studies, Lawrence Wills engaged in a pioneering effort to earnestly investigate the nature, function, and social and historical context of this narrative literature. ${ }^{3}$ To this end, he posited a difference of essence between 'traditional' narratives and the texts composed in Hellenistic and imperial times, which display novelistic features: 'fanciful and idealized settings, entertaining plots, happy endings, and women characters' ${ }^{4}$ Novelistic literature is defined as crossing the boundaries between 'truth and untruth', 'real and unreal, respectable and entertaining, ... restrained and indulgent', and as a counter-genre of sorts which absorbs and mimics the established genres. ${ }^{5}$ Within the corpus of Jewish works, Wills further distinguished between 'novels proper' (or 'novellas') and works using 'novelistic techniques'. The novellas - Greek Esther, Susanna and Bel and the Dragon in Greek Daniel, Tobit, Judith, and Joseph and Aseneth - are defined as narratives whose main protagonists are 'little-known or totally unknown figures from Jewish history', mostly women. Their main theme is 'Jewish piety and identity', and the stories are situated in courts. ${ }^{6}$ In a study of 2011 Wills offered an in-depth and convincing thematic comparison between Judith (and, implicitly, Greek Esther) and the Greek novel of imperial times, pointing to their shared 'entertaining plots, an increasing number of women characters, internalizing psychological focus, interest in domestic settings and values (such as the containment of sexuality), and the manipulation of emotion'. ${ }^{7}$ As he noted further, the Jewish novella antedates the emergence of the Greek genre, while reflecting a different position in society, as the threat at the crux of the plot is experienced from the standpoint of the colonized, not from the colonial angle. ${ }^{8}$

Wills further detected incipient pre-echoes of this novelistic development in a few works composed in Hebrew and Aramaic and which also belong to the sub-

\footnotetext{
2 On Ahiqar, see Humphreys 1973. On 'historical fiction', S. Johnson 2004, 9; Wills 1994, 224, see also Wills 2002; Joseph and Aseneth: Wills 2002; 2011; Testaments: Nickelsburg 1984; Doran 1986; Wills 2002.

${ }^{3}$ See, in particular, Wills 1990; 1994; 1995; 2002; and 2011.

${ }^{4}$ Wills 2011, 141-142.

${ }^{5}$ Wills $2011,144,147-148$. According to him, the genres of historiography and the novel (that is, the genres of 'truth' and of 'untruth') co-originated in the fifth century BCE.

${ }^{6}$ Quotations are from Wills 2002, 4-5.

${ }^{7}$ Wills 2011. Quotation from p. 152.

${ }^{8}$ Ibid.
} 
genre of the court tale-MT Daniel 1-6, MT Esther, and the Prayer of Nabonidus from Qumran (4QprNab). ${ }^{9}$ However, most of the works he identifies as novelistic divide into 'historical novels' and 'novelistic testaments', and were again composed in Greek and for the most, are non-canonical works. ${ }^{10}$ In separate studies, Erich Gruen and Sara Raup Johnson endorsed Wills' approach and further explored what they see as the fictional, entertaining nature of these works. ${ }^{11}$

The emphasis on the fictional, novelistic nature of this Jewish narrative literature breaking free of traditional story-telling is based on several interrelated assumptions, which in my view warrant reexamination. Two key aspects of the theory in particular seem problematic. First, the way the works are grouped privileges what I will call a shared stylistic evolution, which is held as a marker of a genuinely generic shift - the so-called emergence of the Jewish novel. Furthermore, the distinction between works that were eventually included in the Septuagintthe Greek biblical canon - and works that were not, becomes irrelevant. Again, Wills is one of the few scholars to address this issue, claiming that the 'Jewish novellas' retained their novelistic nature until a later stage, and were eventually incorporated in biblical canons, firstly because the characters contained therein eventually came to be revered as 'models of faithfulness', and secondly because these accounts tended to fill in chronological gaps in biblical history. ${ }^{12}$

In itself, this method of grouping texts would be perfectly justified in heuristic terms, were the theory restricted to stylistic aspects and the delineation of new narrative templates. However, the novelization of the works in question is further taken to indicate a shift in the social context in which they were produced (that is, the social identity of their implied authors), in their ideal audience, and correlatively, in their social function. ${ }^{13}$ The transition to the novelistic is described as a direct consequence of Jewish communities thriving in urban centers and enjoying increased literacy. To quote Wills, 'novels... have only arisen where the written medium could be cultivated for entertainment'. ${ }^{14}$ In this new environment, the novelized works catered to the tastes of a wider segment of the Jewish population and addressed its concerns; hence the prominent thematization of eroticism,

\footnotetext{
${ }^{9}$ Wills 1990; 1994.

${ }^{10}$ His anthology (Wills 2002) includes Artapanus, On Moses, The Tobiad Romance, and The Royal Family of Adiabene (both from Josephus' Antiquities); and the Testaments of Joseph, Job, and Abraham.

${ }^{11}$ Gruen 1997; 1998; 2016; S. Johnson 2004; see also Johnson, Dupertuis, and Shea 2018.

12 Wills 2011, 163-164, quote p. 163.

${ }^{13}$ Here and below, the terms 'novelized' and 'novelization' are used as a convenient way to lump together the two sub-categories of the 'novellas' and the 'novelistic works' which Wills distinguishes.

${ }^{14}$ Wills 2011, 144.
} 
chastity, and marriage. Furthermore, it is alleged that, like their Greek counterparts, the Jewish novels had no institutionalized social use but were performed or read purely for entertainment. ${ }^{15}$

This last statement is particularly surprising, because the narratives of LXX Esther and Judith - the two works which according to Wills most clearly support the comparison with the Greek novel ${ }^{16}$ - end with the mention of collective rituals and the establishment of commemorative festivals, suggesting that the relationship between novelization and social function may be more complex than assumed. ${ }^{17}$ Furthermore, the assumption of a correlation between novelization, the identity of the ideal readers, and the social function of the works, has led scholars to emphasize the presence of certain themes in the said works while disregarding others, which could support a totally different understanding of the implied authors, ideal readers and above all social function of the said works.

In this article I explore these alternative threads in a bid to examine afresh the nature of the alleged discontinuity between the traditional tales and the novelized works of Hellenistic times. While the stylistic shift in the cited works - to some extent also thematic - is undeniable, in my view this feature has been unduly turned into a yardstick to which the other aspects of the works are subordinated, such as the identification of family resemblances, the definition of the ideal readership, and not least their social function. If we reverse this hierarchy and instead treat style and tone as secondary, these issues can be apprehended in a very different way. In what follows I will focus on a sample of texts composed in Hebrew, Aramaic, and Greek. Because I believe that in the case of works composed in Greek their inclusion or not in the biblical canon (the Septuagint) is a fundamental criterion of distinction, the Greek works discussed below exclusively belong to the biblical corpus. I will argue that in terms of their social function, the continuity between the 'traditional' forms of story-telling produced in Persian times and the Hellenistic stories is far more palpable than the scholars emphasizing the novelistic shift acknowledge. This claim has direct bearings both on how I propose to interpret the (undeniable) stylistic evolution of the works, and intend to define the social identity of their authors and ideal readership (or, indeed, audience).

My proposition to decouple social function from style and tone also pivots on a wider premise. The emphasis on the novelization of the Jewish texts produced after $200 \mathrm{BCE}$ is part of a wider scholarly current which in recent decades has been keen to stress the decisive contribution of various narrative traditions from

\footnotetext{
${ }^{15}$ Wills 2011, 145-146; see also 2002: 6-15.

${ }^{16}$ Wills 2011.

${ }^{17}$ OG Esther 10:10. On Judith, see below, section 2.3.
} 
the eastern Mediterranean to the emergence of the Greek novel. ${ }^{18}$ This trend understandably explains why the novelization of indigenous forms of story-telling has been scrutinized so intensively over the years. ${ }^{19}$ However, because we lack evidence to apprehend the precise ways of interaction between Greek and nonGreek traditions, reliance on theoretical models is unavoidable. As a popular model of this kind, the link between novelization and urbanization highlights the fundamental role of the social factors in spawning literary changes. Laudable as this tenet is, however, I suspect that this model inadvertently endorses another, far more questionable paradigm that crystallized at a time when indigenous temples - not least, the one in Jerusalem - were held as bastions of conservatism. For years, scholars speculated that Hellenization in Judea led to the emergence of secular elites distinct from the temple families - and was further promoted by these new elites - whereas temple scribes were put on the defensive. ${ }^{20}$ This historical reconstruction is plainly wrong. Both in Ptolemaic Egypt and in Judea under Ptolemaic and early Seleucid dominations, the indigenous elites who manned the royal administrations were fielded from among the local temple personnel, or to the very least belonged to the same families. ${ }^{21}$ This means that in Hellenistic times the temple literati were familiar with their own traditions and Greek literature alike. Consequently, in my view, we need to be more sensitive to the enduring vitality of indigenous literary traditions. By that I mean not only that they were able to actively incorporate Greek aspects that were of interest to them-for reasons that remain to determine-but also that they continued influencing each other. Southern Syria at large (including Judea) had for centuries been a geographical crossroad between Egypt, northern Syria, Mesopotamia, and the Mediterranean, and a crucible of the (far more advanced) neighboring cultures. My premise is that this remained true in Hellenistic times. Particularly prominent - albeit not exclusive-were all influences coming from Egypt, both Greek and Demotic ones. $^{22}$

18 See, for instance, the essays collected in Whitmarsh and Thomson 2013.

${ }^{19}$ See also, for instance, Vines 2002, 69-160.

${ }^{20}$ The most influential works in these respects were (and to some extent still are) Hengel 1969, and Bringmann 1983. See in particular Hengel 1969, 49-50.

${ }^{21}$ For Egypt, see Gorre 2009, 557-603; for Judea, see Honigman (forthcoming2; forthcoming4).

${ }^{22}$ For the circulation of texts across cultural boundaries in general, see Selden 2010. For the circulation of texts between Egypt and Judea in Hellenistic times, see, for instance, Honigman 2016. Two recent conferences cast light on the continued influence of all things Ptolemaic on Judea after the Seleucid conquest of 198 BCE: 'The Period of the Middle Maccabees: From the Death of Judas through the Reign of John Hyrcanus (ca. 160-104 BCE)', the Ninth Nangeroni Meeting, Enoch Seminar, held at Villa Cagnola, Gazzada (Italy), June 10-15, 2018 organized by Andrea Berlin and Paul Kosmin; and 'Les derniers 
In light of all this, to endorse my claim of the functional continuity of Judean ${ }^{23}$ narrative literature from Persian to imperial times, I will bring into my discussion various neighboring traditions of story-telling, and primarily the Demotic one. My argument involves two fronts: first, the Demotic stories (or 'tales') serve as a corpus of comparison regarding the context of production and social function of the biblical stories; second, they provide a novel key for analyzing certain formal features that have played a crucial role in the modern perception of the biblical stories of Hellenistic and imperial times as works of fiction aimed at the entertainment of a popular readership.

I will first dwell further on the novelization and urbanization paradigm, and evaluate various clues that strongly suggest how this fruitful convergence of Greek and Demotic literature took place in the temple environment, at least partially. Subsequently, I will examine the literary feature pivotal to the 'novelistic theory'-whereby, beginning in ca. 200 BCE, Jewish story-telling shifted from traditional genres to the novelistic, light-hearted tone of the Judean stories composed after 200 BCE. From there I will argue that, in continuity with pre-Hellenistic story-telling, the novelized works composed after 200 BCE were instead 'serious' literature. Throughout my discussion I will avoid the term 'genre' wherever possible, since my primary concern here is with the function of the texts and the intentions of their implied (respective) authors.

\section{Reframing the Chronology and Social Setting}

\subsection{Novelization and Urbanization: the Inner Contradictions of a Tenet}

In his earlier studies, Wills endorsed the view positing a 'hiatus' in the production of Jewish prose narrative between 400 and $200 \mathrm{BCE}$, claiming that the works composed before the year 400 followed traditional genres, whereas all those composed after $200 \mathrm{BCE}$ incorporated novelistic features, regardless of the traditional genres from which they were derived. ${ }^{24}$ The transition allegedly hinged on a twofold trend: a shift from texts derived from oral literature to texts originally

Séleucides' organized by L. Graslin and C. Feyel at Université de Lorraine, Nancy (France), November 20-22, 2019.

${ }^{23}$ Even though this distinction is somewhat questionable, I will use the adjective 'Judean' when referring to the culture and inhabitants of Judea specifically, and 'Jewish' when I have both Judea and Judean settlements outside it (such as Alexandria) in mind. 'Biblical' refers to both the Hebrew Bible and the Septuagint.

${ }^{24}$ Wills 1994, 224-225, quotation p. 224. Likewise, Gruen 1998, 1-40, dates the shift to Hasmonean times, meaning after the second half of the second century BCE. 
composed in writing; and the thorough transformation of Jewish social life in the Greek diaspora, by which there emerged an urban class of traders and administrators living in Greek cities. ${ }^{25}$

In subsequent years, this time frame proved to be untenable and was discarded by its original supporters once the redating of various texts showed that there was no such gap in the production of literature in Judea in early Hellenistic times. ${ }^{26}$ The gap theory works on two fronts, however, which were upheld with no further examination. The first relates to the literary quality of the works and endorses a narrative of linear progression from traditional genres of story-telling derived from oral literature toward new genres composed directly in writing. As the theory goes, the former were couched in a plain style supposedly serving a rigid, unsophisticated conception of morality, whereas the subsequent novelization brought along narrative sophistication, irony, and an unprecedented degree of moral ambiguity. ${ }^{27}$ The second tenet is sociological, and posits a direct link between novelization and urbanization, which further requires to assume a radical change in the social identity of the authors of the novelistic works - that is, the composition of the works supposedly moved from the circles of temple scribes to the Hellenistic urban centers.

Upon closer examination, this sociological line of approach can be challenged. For instance, this model is unable to explain how MT Esther and MT Daniel 1-6-which given their language (Hebrew and Aramaic), cannot have been composed in a Hellenistic urban center-display proto-novelistic features. ${ }^{28}$ Likewise, the prevailing date for LXX Tobit is late third or early second century $\mathrm{BCE}$. At this date-if indeed it is correct-none of the most commonly posited places of composition for this work (Judea, Galilee, and Mesopotamia) had as yet undergone any particular rise in urbanization. While in recent years a number of scholars have argued that Greek Judith was original (not a translation) and was composed in the diaspora, most scholars still opine that the story, even though it was composed in Greek, originated in Judea. ${ }^{29}$ It has been reasonably argued that Judith parodies a Hasmonean founding myth narrated in 1 Maccabees 7,26-49 and 2 Maccabees 15,1-36, which allows us to securely date Judith to Hasmonean times. ${ }^{30}$ However, some scholars also interpret the story of the averted massacre

\footnotetext{
${ }^{25}$ Wills 1994, 226-227; 2020, 15-20; 2011;

${ }^{26}$ For a survey, see Honigman (forthcoming1).

${ }^{27}$ This aspect can only be addressed succinctly in this paper (below, section 3.1).

${ }^{28}$ As argued in Wills 1990; 1994.

${ }^{29}$ For an overview, see Gera 2014, 79-94.

${ }^{30} \mathrm{On}$ its parodic nature, see below, section 2.3, with $\mathrm{n} .70$.
} 
in MT Esther as an allusion to Antiochus IV's so-called religious persecution and situate the work's composition in Hasmonean times. ${ }^{31}$

Taken together, these given would mean that two works displaying very different levels of novelization were composed at roughly the same place and time, the implication being that urbanization cannot be the discriminating factor. Moreover, elsewhere I have argued that 2 Maccabees was composed not in Alexandria but in the Hasmonean court in Jerusalem in the early days of the dynasty, that is at the time when the urban development of Jerusalem was definitely still incipient. ${ }^{32}$ Now, this work - and in particular the Heliodorus episode in 3.1-4.6-is framed in the Hellenistic style of historiography once labeled 'tragic history', and which supposedly appealed to the same readership as the novels. If my theory is correct, it implies that the style of 2 Maccabees was an imitation of a Greek genre, produced by an author and in a social environment very different from those imagined for the novels. In the same way, we cannot rule out that the novelization of the biblical stories resulted from the combined reception of Greek Hellenistic historiography and comedy, not from an inherent social development, and that the difference between MT Esther and LXX Judith stemmed from a deliberate choice by the authors, regardless of their social identities, and were in particular related to their choice of language (Greek vs. Hebrew). ${ }^{33}$

Unfortunately, as we see, the discussion of these issues rapidly runs into intractable problems because of entrenched disagreements among scholars regarding the time and place where these works were composed, and sometimes also their original language. Nevertheless, there are two ways to tackle these hurdles. One is precisely to use the premise of a direct link between novelization, urbanization, and the shift in the social identity of the works' authors as a tool for situating the composition of the novelized works in time and space. In my view, this approach still stumbles over the identification of two works composed in Semitic languages-MT Daniel 1-6 and MT Esther-as proto-novelistic; notably, the overwhelming majority of scholars consider that the apocalyptic section of Daniel 7-12 was completed before the death of Antiochus IV in $175 \mathrm{BCE}$, and after the section of the court tales, meaning long before any urban development in Judea. The other is that we do away entirely with the links between the three aforementioned processes and examine the issues anew.

\footnotetext{
${ }^{31}$ Macchi 2018, 44-52, and passim; Bezold (forthcoming). See further below, section 2.3.

32 Honigman 2014. According to archaeological findings the urban development of Jerusalem started under the Hasmonean dynasty, and never became anything impressive. Furthermore, Jerusalem was the only city in Judea. See Lipschits 2011.

${ }^{33}$ On the theatrical and emotional style of Greek historiography, see Chaniotis 2013.
} 
This is the path I intend to explore. To summarize, I suggest that temple scribes - in Judea, Egypt, and presumably elsewhere - were fully conversant with the scientific, intellectual, and literary innovations at large in the world around them, an awareness that had been true for centuries, and continued in Hellenistic times. These erudite figures were perfectly able to imitate - or mimic - the novelistic features of Greek historiography, incipient Greek story-telling harking back to Xenophon's Cyropaedia, and the themes of love and happy ending in marriage that are the brand of Greek New Comedy and presumably outlived Menander. ${ }^{34}$ From their point of view, however, they continued to produce stories for the same reasons and purposes they had always done. That is to say, the shift in style is not evidence of a change in function. To bolster this argument we may turn to the Demotic narrative literature of Hellenistic and imperial times, which offers important material for comparison. ${ }^{35}$

\subsection{Reframing the Chronology and Social Setting: The Contribution of Demotic Narrative Literature}

Three villages from the Fayyum (Middle Egypt)—Tebtunis, Soknopaiou Nesos, and Narmouthis - have yielded Demotic texts in association with archaeological contexts. ${ }^{36}$ Because the Fayyum was a partly artificial oasis created by the first Ptolemies and eventually reclaimed by the desert in the late first millennium CE, a disproportionate number of papyri, both documentary and literary, come from this area. However, the presence of literary texts in villages in the Fayyum has further been explained by the peculiar organization of the Arsinoite nome (administrative district) situated there. Because of this history, in contrast with the nomes of the Nile Valley, it lacked a strong capital, and as a consequence important temples were located in villages. ${ }^{37}$

The most important collection of Demotic literary texts comes from Tebtunis. It was discovered in a single deposit bordering the Sobek temple, which was

${ }^{34}$ On Menander, see Gutzwiller, 2007, 50-60. Scholars have long since identified influences of Greek philosophy on sapiential works produced in Hellenistic Judea such as Ecclesiastes. See, for instance, Krüger 2004, 12-14.

${ }^{35}$ For surveys of Demotic literature, in particular short stories, see Depauw 1997; Tait 1996; 2012; Quack 2009; and Holm 2013. For anthologies of texts in modern translations, see Lichtheim 1980; Hoffmann and Quack 2007; and Agut-Labordère and Chauveau 2011. The term of 'tales' is sometimes used to define the Demotic stories. Given that to modern ears, this term denotes popular literature, I will refrain from using it.

${ }^{36}$ See the survey in van Minnen 1998.

${ }^{37}$ Ibid., 101. 
identified as the temple's library (House of Life) ${ }^{38}$ Sixty out of the 230 Demotic texts belonging to the library - roughly twenty-five per cent - are of the narrative type.$^{39}$ Most manuscripts from the library collection are dated to the first and second centuries $\mathrm{CE}$, but to judge from the content of the narratives, the works were likely composed in Hellenistic times. ${ }^{40}$

\subsection{Greek Borrowings in Demotic Narratives}

The temple personnel from Tebtunis was perfectly bilingual, as attested by the incidental presence of Greek documentary papyri in the library collection. The collection also included a limited number of Greek literary works, namely two medical treatises and an astrological calendar. ${ }^{41}$ Moreover, the bilingualism of Egyptian scribes in the Fayyum in Hellenistic times is also well documented-the period in which the works were presumably composed. ${ }^{42}$

The temple scribes who composed the narratives found in the Tebtunis library were also well versed in Greek literature and put their perusals to good use. A Greek mythological motif and a literary topos inspired the story Egyptians and Amazons situated in India - with which, as Peter van Minnen noted, actual contacts had increased in early imperial times. ${ }^{43}$ Likewise, Ian Rutherford convincingly identified Homeric epic influences in the narrative cycle of Inaros, whose warlike hero was subtly equated with Achilles, while Kim Ryholt spotted allusions to Alexander. ${ }^{44}$

\subsection{Summary}

As we can see, the provenance of the texts and the dates of the papyri from the Tebtunis library prove that in Egypt 'traditional narratives' remained a lively genre well into imperial times, occasionally borrowing themes and forms from Greek literature. ${ }^{45}$ The temple scribes continued to copy them, and while temple

${ }^{38}$ Ryholt 2005: 157-158. Ryholt (pp. 157-163) further refutes the doubts about the nature of this temple deposit raised by van Minnen $(1998,109)$.

${ }^{39}$ Ryholt 2005, 147.

${ }^{40}$ Ibid., 146; Dieleman and Moyer 2010, 432.

${ }^{41}$ Ryholt 2005, 143-144. On the priests' bilingualism in Tebtunis and Soknopaiou Nesos, see also van Minnen 1998, 108-110, 167-168.

${ }^{42}$ See Clarysse and Thompson 2006, 127, 129.

${ }^{43}$ Van Minnen 1998, 169.

${ }^{44}$ Rutherford 2016; Ryholt 2013.

45 The study of Demotic borrowings from Greek literary devices is only at its inception. According to Damien Agut-Labordère there is at least one example of a Demotic ekphrasis, 
personnel and literati must have remained their primary readers, like the myths, narrative literature was obviously widely known among the general population, as well.

Now this narrative literature originating in the Egyptian temples precisely constitutes the corpus of texts that contributed to the emergence of the Greek novel. Even though a few Greek translations confirm that they were also circulated independently of any institutional setting, in my view this is no reason to dismiss their priestly origins, all the more since the narrative literature from Tebtunis has yielded the Demotic originals of a number of stories featuring in the historical part of Herodotus' Egyptian logos, implying that the novelistic undertone of Herodotus' Histories has its roots in temple literature. ${ }^{46}$

Likewise, the narratives belonging to the Tebtunis temple library share with their Judean counterparts some of the stylistic and thematic features that have supported the latter's description as proto-novelistic or novelistic. In truth it is not always possible to determine whether the affinities between Judean and Demotic literary works are the fruit of cross-cultural borrowings or parallel inventions. Moreover, the geographical location of Judea could easily warrant influences from the North (Syria) and the East (Babylonia), and the shared incorporation of Egypt and Palestine in the Achaemenid imperial space may complicate matters further. ${ }^{47} \mathrm{~A}$ few specific features, however, are best explained as borrowings from the Demotic tradition specifically. Below I discuss affinities relating to style, form, tone, and content. I will try to distinguish between affinities of uncertain source and influences or borrowings. I start with tone.

providing a case of generic borrowing (personal communication, July 2018). See also below, n. 55.

${ }^{46}$ Demotic works for which a Greek version is documented include the Myth of the Sun's Eye, the Dream of Nectanebo, and the Oracle of the Potter. See, for instance, Tait 1994, 213-215. The stories of Pharaohs Sesostris and Pheros in Herodotus 2,102-111 feature in the Petese story sequence that belonged to the Tebtunis library. On the Demotic texts underlying Herodotus' Egyptian logos, see Widmer 2002; Dieleman and Moyer 2010, 436; and below, section 3.4.

${ }^{47}$ The sub-genre of the court tale seems to have been imported in Egypt under the Achaemenid domination. See Wills 1990: 42-43. Its importation into Judea could come from Babylonia, its supposed place of origin, or through imperial power-brokers at home, or through the mediation of Egypt. The story of Ahikar is documented in an Aramaic papyrus from Elephantine, where a military colony of Judeans was settled. Demotic copies of Ahikar dated to the first century CE were discovered in Soknopaiou Nesos (Van Minnen 1998, 152). Holm (2013) argued that Daniel 1-6 was composed in Egypt. 


\section{Diverting the Reader—or Audience}

Advocates of the 'novelistic theory' tend to emphasize the light-hearted tone of the Judean stories composed after $200 \mathrm{BCE}$, and indicate this feature as evidence of a shift in the social identity of their authors. In truth, wit and amusement were nothing new in Hellenistic times, and we therefore need to define what was actually new in this novelistic shift of Hellenistic times. Moreover, the theory misrepresents the social function of this diverting style. In truth, in the ancient Mediterranean religious systems the temple personnel were anything but solemn moralizers or corseted prudes. ${ }^{48}$

\subsection{Fun vs. 'Popular' in Egyptian and Demotic Story-telling}

As it turns out, Egypt had a long tradition of diverting writings. In his study of Egyptian literature of the Middle Kingdom Period (ca. 2030-ca. 1640 BCE), Richard Parkinson identified stories (such as the Tales from Cheops's Court) that contained allusions to esoteric lore that were deliberately cited in incongruous and even frivolous ways for humorous effect. In his view, the learned references in the texts situate both their authors and audience squarely among the elite, yet the style indicates they were for recreational purposes. ${ }^{49}$ It should be noted moreover that in the Middle Kingdom period the diverting quality of narrative literature was fully acknowledged, and various collections of stories were bookended by a pharaoh requesting to be entertained with tales, while longer narrative works of the period were not devoid of irony. ${ }^{50}$

While erudite parodies became less frequent in the later periods, Demotic story-telling endorsed the long tradition of collected tales. The Story of Amasis and the Sailor kicks off with Pharaoh Amasis suffering from a hangover and arranging some entertainment to alleviate his plight. ${ }^{51}$ The Myth of the Sun's Eye comprises a frame-story relating how the 'son of Thoth' was sent to Nubia, where Tefnut, the daughter of the sun-god, had fled, in order to induce her to return to Egypt. Within this frame, readers are treated to animal fables, by means of which Thoth seeks to both placate and instruct Tefnut. ${ }^{52}$ The Story of Petese tells how

\footnotetext{
${ }^{48}$ I do not distinguish between temple personnel and royal scribes. For pre-Hellenistic periods, there is plenty of evidence proving that the former provided the latter. For Hellenistic times, see above, n. 21.

49 Parkinson 2002, 138-146.

${ }^{50}$ Irony is discernable in The Eloquent Peasant, a narrative dating to the Middle Kingdom. See Lichtheim 1973, 169. The earliest satire also dates to this period. See ibid., 184.

${ }^{51}$ Traditions about Amasis' love for drinking were already known to Herodotus (2.174).

${ }^{52}$ Quack 2009, 148-160.
} 
the hero, a priest of the Sun-god in Heliopolis, learns that he must soon die. In response he creates certain magical beings and orders them to gather up and put in writing thirty-five stories relating the virtues of women, and an equal number on their vices - one pair of stories for each of the remaining days of his life. ${ }^{53}$

Yet, the fact that narratives comprised twenty-five per cent of the temple library collection in Tebtunis clearly indicates that entertainment per se was not the primary purpose of these stories. ${ }^{54}$ As Kim Ryholt notes, the collection of stories devoted to virtues and vices in the Petese collection belongs to moralistic literature, and that the Myth of the Sun's Eye is also didactic, and 'parts of [it] can be described as philosophical'. ${ }^{55}$

While collections of short stories admittedly do not provide a continuous, 'entertaining plot' - the hallmark of novels-Demotic narrative literature also included longer works, some of them forming cycles centered on recurring heroes. The two most prominent cycles featured Petubastis II of Tanis and Inaros of Athribis who fought against the invading Assyrians, and Setne Khaemwas, an ancient priest of Memphis and prominent magician, respectively, and in his study of the Inaros cycle, Friedrich Hoffmann suggested that it was intended as entertainment. ${ }^{56}$ However, Kim Ryholt objected that the Inaros-Petubastis cycle belongs with a set of stories featuring past pharaohs - Inaros, Nakhthorshen, Djoser, and Sesostris-'placed in fictitious situations where they defeat and humiliate' foreign invaders, and which together form more than half of the narrative material from Tebtunis. ${ }^{57}$ Admittedly, these texts require some decoding, because they endorse a way of memorializing the past that is entirely at odds with Greek historiography; however, when read with the correct references in mind, they clearly belong to the historical genre. ${ }^{58}$ As discussed below, the Book of Judith and the Inaros cycle share not only the theme of the hero withstanding a foreign invaderwhich it parodies - but the Demotic rules of historiography. ${ }^{59}$

Notably, Ryholt groups these stories about pharaohs resisting invasions with 'another and smaller group of narratives [centering on] prophecies which-it may be assumed - predict a future where Egypt will prevail over its enemies and

\footnotetext{
${ }^{53}$ Ryholt 1999, 69.

${ }^{54}$ For this argument, see Dieleman and Moyer 2010, 436.

${ }^{55}$ Ryholt 2005, 163. The philosophical slant could denote a Greek influence.

${ }^{56}$ Hoffmann 1996, 22. Demotic tales are sometimes organized in narrative cycles. Inaros is one of the three documented ones. See Dieleman and Moyer 2010, 435-436.

${ }^{57}$ Ryholt 2005, 163. On the Inaros-Petubastis cycle, see further Quack 2009, 50-70.

${ }^{58}$ See further below, section 3.2.

${ }^{59}$ See section 3.2.
} 
achieve its former glory', an interesting way of decompartmentalizing 'narrative literature'. ${ }^{60}$

The first story of Setne Khaemwas comes even closer to the accepted definition of the novelistic. ${ }^{61}$ The plot depicts how Setne Khaemwas summons from the dead Naneferkaptah, a royal prince, learned scribe, and magician, who was buried in Memphis and also his late wife Ihweret, because he coveted a magic book written by the god Thot himself, and which was in Naneferkaptah's possession. After Khaemwas managed to get hold of the book in a tricky manner, he fell in love with the beautiful Tabubu whom he met in the temple of Memphis. However, Tabubu turns out to be a supernatural being who humiliates him, and once Khaemwas realizes that she was sent to him as a form of punishment, he mends his ways.

Interestingly, the narrative cycle of Setne Khaemwas has a proven connection with the Greek novel. It has been asserted that the story of Sethon, priest of Ptah in Memphis, in Herodotus (2.141) is related to it, and moreover Ian Rutherford has convincingly argued that the figure of the Egyptian priest Kalasiris in Heliodorus' Aethiopica was loosely based on that of Setne Khaemwas. ${ }^{62}$ However, as Stephen Vinson has shown, the complex plot of Setne Khaemwas I was not simply entertaining - although it certainly is that too. Rather, it had a deep religious overtone. The subplot narrating the story of how Naneferkaptah obtained the magical book, which is told by his wife, is heir to a well-attested genre of allegorical tales informed by the myth of Isis and Osiris, but at the same time it responds to contemporary religious developments in that it acknowledges the prominent place that Isis acquired in Hellenistic and imperial times, and in this illustrates the gap between Demotic and Greco-Roman story-telling. ${ }^{63}$ The latter borrowed whatever good stories happened to be at hand, and repurposed them to address the needs and concerns of readers as individuals. In Demotic tales the issues tackled were not only of collective interest, but they fit into categories of knowledge that met priestly concerns.

\subsection{Judean Echoes}

Unfortunately, Jewish literature does not problematize the humorous aspect of story-telling in as explicit a way as the Egyptian, and therefore modern readers

\footnotetext{
${ }^{60}$ Ryholt 2005, 163.

${ }^{61}$ For a summary of the two extant stories belonging to the Setne Khaemwas cycle, see Rutherford 1997, 205. On the first tale, see Vinson 2018.

${ }^{62}$ Rutherford 1997, 205.

${ }^{63}$ Vinson 2008, 305.
} 
must rely on their subjective perception of the works to assess their tone. As Philip Davies long since noted, texts potentially qualifying as 'diverting' are scattered throughout the entire biblical corpus, citing the Joseph story in Gen 37-48; the Succession Narrative (the family history of David) in 2 Samuel 2-20 and 1 Kings 1-2; the Book of Ruth in the Writings; and the Book of Jonah among the Twelve Minor Prophets. ${ }^{64}$ Moreover, Carol Newsom convincingly applied Mikhail Bakhtin's theory of dialogism - an alleged hallmark of the novel - to the Book of Job, a poetic work usually dated to the Persian period, and which addresses profound moral issues about theodicy. ${ }^{65}$

While advocates of the 'novelistic theory' acknowledge the existence of these texts and some thematic continuities between them and Hellenistic compositions, they insist that novelization is of an entirely different order. However, once we establish that the novelty in Hellenistic times was not the entertaining quality of the stories per se, but the appearance of certain themes and stylistic features, there is ground to further ask whether the said characteristics - 'fanciful and idealized settings, entertaining plots, happy endings, and women characters' - necessarily require that the works in question were composed for mere entertainment. ${ }^{66}$ As just noted, entertaining stories existed already, and the prophetic book of Jonah and the poetic book of Job are as arresting as MT Esther. To phrase the matter in a less tautological manner, the question is whether in terms of their function the Jewish novelistic works that were eventually included in biblical canons-MT Esther and Daniel in the Hebrew Bible, and Greek Esther, Daniel, Judith, and Tobit in the Septuagint - share basic affinities with Demotic tales, and hence belong to the category of traditional story-telling (while, admittedly, updating it), or genuinely prefigure the Greco-Roman novel.

The answer requires us to pinpoint with greater precision in what the novelty consisted. To my mind, it boils down to style - appealing to emotions - and some reprocessing of traditional themes, such as sexuality. Moreover, I argue that some features widely held as defining attributes were misinterpreted. In particular, the use of generic names and alleged historical inaccuracies that are confused for remnants of popular literature circulated in oral form actually belong to the historiographical codes (newly) borrowed from non-Greek traditions; these are discussed

${ }^{64}$ Davies 1998, 142-151.

${ }^{65}$ Newsom 2002; 2003. Job is a wealthy and pious man, until Satan persuades God to put him to trial, betting that if Job loses everything he has, he will eventually curse God. As Job suffers his horrible reversal of fortune his three friends offer variegated advices. The most interesting modern interpretations of the work suggest that the final scene in which Job confronts God remains inconclusive, leaving the work truly polyphonic. Beside Newsom, see Krüger 2007.

66 The quote is from Wills 2011, 142. 
below, ${ }^{67}$ but for the moment I will focus on happy endings, fanciful settings, and female characters.

\subsection{Recategorizing 'Happy Endings'}

The Egyptian works from the Middle Kingdom Period that parody esoteric lore and were presumably composed for recreational occasions could meet Wills' understanding of 'popular' literature as a vehicle detached from an institutional setting. However, it is a question whether the biblical corpora truly include works of a similar nature.

The only viable candidate for comparison is the Book of Judith, which some scholars suggested was a parody of a Hasmonean myth narrated in 1 Maccabees 7,26-49 and 2 Maccabees $15,1-36$. $^{68}$ According to the said myth, an enemy (Nicanor) threatened to destroy the temple, but his evil design was finally averted and the temple and hence the Judean people were saved. Judith severing Holofernes' head is considered to echo Judas Maccabee's decapitation of Nicanor. Although Judith 16,18-20 mentions a rite of sacrifice, not the establishment of a festival, the victory over the Seleucid general was commemorated in a Purim-like festival (Nicanor's Day) held on the $13^{\text {th }}$ day of the month of Adar, 'one day prior to the Day of Mordecai' (2 Macc 15,36; 1 Macc 7,49). ${ }^{69}$

Moreover, in terms of the stock narrative template (temple and/or Jews are threatened with destruction, but danger is averted and a commemorative festival instituted), the story of Judith is very similar to the Book of Esther. For this reason, it has been suggested that like Esther, the Book of Judith is a case of carnivalesque literature rather than a parody. ${ }^{70}$ In Antiquity carnivalesque literature was linked to festivals, and that was certainly the case with the MT Book of Esther (linked to Purim) in Judea. ${ }^{71}$ Therefore their whimsical tone and use of eroticism have nothing to do either with a popular origin in the traditional sense, or with 'popular literature' in the meaning of 'free of institutional setting and performed purely for

${ }^{67}$ See sections 3.2 and 3.3 .

68 Van Henten 1995.

${ }^{69}$ Macchi 2018, 267-281, makes the cogent case that the date of Purim - which in Esther's account is quite arbitrary-refers to Judas' victory over Nicanor. As he notes, Nicanor's Day belongs in a series of festivals commemorating military victories that were instituted in the days of the Hasmoneans. See ibid., 270, n. 116.

${ }^{70}$ Esler 2002; and Honigman (forthcoming3). For MT Esther as a carnivalesque work, see Craig 1995; Lacocque 2007. The definition of carnivalesque literature harks back to Bakhtin 1984.

${ }^{71}$ Compare the Dionysia in the Greek realm. Aristophanes' comedies are typically carnivalesque. 
entertainment' tendered by Wills. ${ }^{72}$ The genesis and function of the text are more complex.

As noted above in the overview of Demotic narrative literature, ancient Mediterranean traditions of story-telling were dynamic. For example, some scholars have (and in my view, cogently) argued that MT Esther and Judith respectively responded to a recent event, namely Antiochus IV's storming of Jerusalem and its temple in 169 or $168 \mathrm{BCE}^{73}$ The fanciful transposition in time and place applied in the two works allowed the temple (or court) literati who composed them to revisit the significance of the fateful events, and in this way impact social memory. To compose the works, they exploited contemporary genres and literary devices drawn from multiple sources. Thematically speaking, the court tale that shapes Esther had been an established genre in the region since Persian times. The Judean literati may have borrowed it directly from Eastern models, or from Egypt, where it had been assimilated much earlier than in Judea. A long tradition of interpretation argues that the slaughter of the Jews' enemies in Judith 8-10 derive from the mythic transposition of the Assyrian royal ideology, according to which royal acts of revenge were carried out by gods. ${ }^{74}$ That said, Daniel Macchi recently argued that the Persian motifs in Esther were entirely inspired by Greek literature, more particularly Herodotus, and that the story of the massacre of the enemies reworked the account of Antiochus IV's slaughter of the population of Jerusalem when he stormed the city in 169 or $168 \mathrm{BCE}$, which is found in $1 \mathrm{Mac}-$ cabees $(1,41-64)$ and 2 Maccabees $(6-7){ }^{75}$

Likewise, it seems that the storyline in Judith exploits literary precedents rather than genuine historical events. In particular, Herodotus' Histories are cited as shaping the story of the foreign invasion and of the figures of Nebuchadnezzar and Holofernes, and it seems that the allusions to the Maccabean wars refer not to the events per se but to 1 Maccabees. ${ }^{76}$ Moreover, in the last part of the book (Jdt 7-13) the heroine is depicted as a female Moses. ${ }^{77}$ In terms of style, Judith exploits the generic codes of Greek historiography, in particular speeches, and the

72 Wills 2011, 145-146.

${ }^{73}$ Macchi 2018, 44-52; Bezold (forthcoming). Macchi points to the numerous thematic similarities between Esther 8-10 and 1 and 2 Maccabees, and convincingly argued that these final chapters - together with selected verses in others - were an addition to a proto-Esther text that were composed in Judea after 1 and 2 Maccabees, meaning in the late second or early first century BCE.

${ }^{74}$ See, for instance, Dalley 2007.

${ }^{75}$ Macchi 2018. On Esther as a Persica in the Greek style, see pp. 41-44. On the Vashti story in Esther 1 and Herodotus, see pp. 91-114. See further pp. 257-258. On intertextuality between Esther and 1 and 2 Macc, see pp. 44-45, 258-259, and 285-298.

${ }^{76}$ Caponigro 1992; Eckhardt 2009.

${ }^{77}$ Van Henten 1995. 
stylistic flourishing of the Greek Books of Esther (Old Greek and Alpha) compared to their Hebrew counterpart may be explained in the same way. ${ }^{78}$

These disparate literary materials were skillfully combined and shaped according to an indigenous narrative template whereby the two narratives were imbued with a deep religious resonance that also lent historical meaning. ${ }^{79}$ Esther (in all its various recensions) and Judith are stories of divine salvation, and in this respect they belong with a number of biblical works that attest to the wide reception in the period that followed the compilation of the Pentateuch in Persian times, of what is sometimes inappropriately dubbed Deuteronomic scheme of history. The full-fledged template includes the four components of sin, retribution, reconciliation, and salvation, whereas the pattern of threat and salvation shaping Esther, Judith, and 3 Maccabees may be seen as a variant. ${ }^{80}$ Now, when it comes to the purpose and social function of a work, collective salvation with a religious overtone takes us very far from the 'happy ending' of the Greek novel. The difference between the two cannot be played down as merely thematic variants.

\subsection{Female Characters and Eroticism in Jewish Narrative Texts}

With the rise of Isis' religious status in Hellenistic times, eroticism and sexuality became a prominent theme in Demotic narratives. ${ }^{81}$ As Stephen Vinson notes, 'the conspicuous thematization of femininity and female characters' in the Egyptian prose fiction tradition derives from the mythology of Isis and Osiris. ${ }^{82}$ Notably, the view of womanhood they purvey echoes the discourse on women typical of Demotic instruction texts. ${ }^{83}$

In light of the multiple influences discernible in Esther and Judith, I suspect that the appearance of marginal characters and female heroes in Judean literature beginning in Persian times - Ruth and Boaz, Esther, Judith, Job, and Tobit—were first inspired by the Egyptian and Demotic traditions, in which such women were stock figures. The Judean wisdom tradition was not averse to using bodily metaphors, erotic and culinary, to stimulate the ethical imagination of the young scribes it was intended to educate, as attested in Proverbs by the image likening wisdom to the 'good wife', and the new narratives helped round out the youths'

\footnotetext{
${ }^{78}$ Schmitz 2015.

${ }^{79}$ What I mean by 'historical' is clarified below, section 3 .

${ }^{80}$ In truth this understanding of history was shared by several ancient Near Eastern societies and not specific to the Judean Book of Deuteronomy. See Pury, Macchi, and Römer 2000.

${ }^{81}$ On eroticism in Setne Khaemwas, see Vinson 2018, 256-260, 265-266. See further Vinson 2016.

82 Vinson 2008; 2016, 245.

${ }^{83}$ Dieleman and Moyer 2010, 436.
} 
instruction ${ }^{84}$ In Hellenistic times, the prominent female figures peopling Herodotus' Oriental courts certainly played a role too, and provided new contexts for staging women (Candaules' wife in 1,7-12; and Amestris in 9,108-116).

Wills convincingly argues that the plots in Judith and Greek Esther (partly) pivot on the kind of ambiguous sexual tension that was to characterize the Greek novel, while a gap separates the concept of love and sexuality that underpins the earlier narrative works and collections of proverbs, and the eroticism found in Judith, Esther, and the novel. ${ }^{85}$

However, once again, we need to zero in on what was really innovative in the plots of these two biblical novellas. The royal myths that developed around the women of the Greco-Macedonian dynasties must have been key to this evolution. As far as we can discern from the late sources recounting them, they merged staple plots borrowed from Greek historiography - and possibly also from Greek New Comedy - with themes and narrative templates derived from Greek and local religious traditions. Thus in Egypt Ptolemaic queens and princesses were identified with Aphrodite, Demeter, Hathor and Isis, ${ }^{86}$ whereas in Syria, the stories featuring queen Stratonice, Seleucus I's wife, apply narrative templates borrowed from myths related to the Syrian goddess, Atargatis. ${ }^{87}$

The new production of Judean self-contained stories featuring women in prominent roles may reasonably be interpreted as a response to the combined effect of these multiple influences: Demotic and Syrian mythical material and narrative traditions, Greek historiography and Greek New Comedy — which provided the stock plot of a love story between two young people with marriage as a happy finale - and the royal myths reflecting the prominence of queens and princesses in the Hellenistic courts. Altogether the Judean stories thematized various aspects of femininity: the theme of marriage is covered in Ruth and Tobit; Esther and Judith toy with eroticism; whereas Salome in Mark's Gospel represents an even more threatening type of woman. ${ }^{88}$ I suspect, however, that the specific Jewish contribution to eroticism was not to promote it in an innovative way, but instead aimed to realign it with the paradigm of collective salvation, reshaping it into a carnivalesque motif. And let us not forget that in Judith and Esther marriages occur at the beginning of the plot, not at the end.

As noted in the introduction to this article, when Esther and Judith are primarily defined as Jewish novellas, we can only puzzle how they eventually made their

\footnotetext{
${ }^{84}$ See Stewart 2016.

${ }^{85}$ Wills 2011.

${ }^{86}$ Van Oppen de Ruiter 2007.

${ }^{87}$ Ogden 2017, 174-246.

${ }^{88}$ Here I make use of a personal communication by Lawrence Wills (May 2020).
} 
way into the biblical corpora (Hebrew and Greek). If instead we focus on the works' ending - the institution of a commemorative festival rounding up the shortened variant of the Deuteronomic scheme of history - as the defining criterion, the dilemma evaporates: not only do the two Greek versions of Esther include reference to the festival of Purim (OG F,10; Alpha 10,59/F,10) but, tellingly, the colophon of OG Esther $(F, 11)$ states that the text was brought to Egypt by 'a priest and a Levite', whereas the identity of the translator (or of the real author) was omitted altogether. ${ }^{89}$ Therefore, despite the differences in style and tone compared to their Hebrew counterpart, I see no reason to doubt that the Greek Books of Esther (Old Greek and Alpha) retained a similar social function. ${ }^{90}$

\subsection{Summary}

Judean stories and the early Greek novel drew from similar sources - such as Demotic narratives, Hellenistic royal myths reworking indigenous templates, and Greek historiography - explaining their broad thematic affinities. Moreover, Demotic and Jewish narratives appropriated Greek Hellenistic literary codes, including the innovative stress on emotional appeal. Demotic and Hebrew compositions did it to a limited extent, whereas Jewish texts written in Greek - either as original works or translations - did it massively, regardless of the place where they were composed..$^{91}$

While the motives for Jewish authors going novelistic may have been varied, the evidence suggests that they were primarily literary. As we saw, the culture of writing stories in a diverting tone was traditional, and moreover, some (if not all) the texts discussed above were read aloud to an audience, not perused silently by individual readers. Given the low rates of literacy in Demotic and (possibly also) Hebrew, this was certainly the case with texts composed in these languages, ${ }^{92}$ and moreover the works serving as etiological narratives in festivals-Esther, Judith (?), and 3 Maccabees - must have been performed at the occasion of the said festivals. This performative interaction with audiences must have been a strong

${ }^{89}$ See Karen H. Jobes' translations of the two texts in NETS.

${ }^{90}$ On Judith, see above, section 2.3.

${ }^{91}$ Assuming that (Greek) Judith and 2 Maccabees were composed in Jerusalem.

92 The Story of Petese opens with the words 'The voice which is before pharaoh,' and according to Ryholt, "the word "voice" recalls the fact that stories were meant to be spoken aloud to an audience rather than read.' See Ryholt 1999, 69. The Book of Esther is performed in synagogue rituals. When I attended the Yom Kippur ritual in a Parisian synagogue in my twenties with a friend who would become a teacher of literature, we eagerly awaited the recitation of the Book of Jonas as a welcome recreation from the dark atmosphere of the day. 
incentive for the scribes to try and keep their stories up to their audience' expectation of having a good time. To this end, they would have been eager to appropriate new literary devises to make the performance more successful. Regarding the emergence of female characters in Hebrew literature, trends already noticeable in sapiential literature spread further under the influence first of the Demotic narratives, and later that of Greek stories. This dynamic was all the easier because the traditional story was malleable enough in terms of form to incorporate multiple influences and follow the tendencies of the day, while remaining anchored to an institutionalized setting. Contrary to the urbanization model, this scenario could explain the novelization of texts produced in Judea, either in the temple or the Hasmonean court.

\section{Novelized Works as Serious Literature: Their Relationship with History}

As I argued in section 2, there are fundamental differences in the way Demotic, Jewish, and Greek texts reconnoitered the theme of femininity. In the Egyptian tradition, all discussion of womanhood was eminently of a religious nature, whereas Greek circles secularized the theme when they acclimated it into their own indigenous production. In between, Jewish writers effected their own variations: decontextualizing borrowings from Demotic traditions, appropriating Greek eroticism, and subordinating all this varied material to their own religious paradigms. In order to corroborate this interpretation, we first need to do away with certain features frequently cited as 'evidence' that the authors (and readers/audiences) of these texts conceived and perceived such tales as fiction, and therefore 'untrue'.

\subsection{The Oral and Popular Origins of Biblical Narrative Works Revisited}

The general consensus of research has long been that biblical narratives originated in popular literature circulated in oral form, and to a large extent this view has remained. This theory serves to explain various features which to modern Western readers are either disconcerting or the hallmark of folktales. Several scholars have shown that biblical stories (including the 'novelistic' Daniel 1-6 and Tobit) could be analyzed using the typology of basic characters and plot components recurring in folktales as first elaborated by Vladimir Propp based on Russian folktales, or with the Aarne-Thompson-Uther (ATU) classification system. ${ }^{93}$ Moreover,

${ }^{93}$ Niditch and Doran 1977; Niditch 1987; on Daniel 1-6, see Milne 1988; on Tobit, see Soll 1988. See also the excellent survey of this approach in Wills 1990, 3-10. 
scholars point to such formal occurrences as generic names and terms in Judith ('Judith', literally 'the Jewess', is an ethnonym turned into a personal name; Bethulia, the name of Judith's town, means 'Virginity'; we may add 'the king' in 1 Macc 1,41), or features that modern scholars characterize as historical inaccuracies ('Nebuchadnezzar king of the Assyrians' in Judith 1,1, whereas he was a famous Babylonian king; he converts to the God of Israel in Daniel; and 'Esther queen of Persia', who is a character of fiction).

However, this line of explanation is unsatisfying for at least two reasons: first, it assumes a clear-cut distinction between generic features and contents associated with popular and elite literature, which, while the equation might be acceptable for nineteenth-century Europe - when the Brothers Grimm and Hans Christian Andersen collected folktales - hardly applies to the ancient times and the wholly different cultural environment under discussion here. Admittedly, a similar distinction between popular and learned literature is attested in the Greek cultural sphere, in which elite authors such as Aristotle acknowledged the practical value of 'popular stories' for instilling standards of ethical behavior. ${ }^{94}$ However, one might argue that the categorizing of certain texts as 'popular' in Greek culture (and also the way this category was defined in literary terms) resulted directly from the specific social organization of the Greek polis, which encouraged the development of highly codified genres aimed for mass consumption in the various institutionalized and semi-institutionalized settings: tragedies in the theater, and oratory, forensic, and epideictic speeches in the assembly, the court, the agora, and the public section of the cemetery.

In contrast, the narrative conventions that shaped elite literatures in the societies of the Ancient Near East were markedly different. ${ }^{95}$ In Demotic literature, (to quote John Tait) certain narrative features such as 'word for word repetition of long or short passages' suggest that although the texts were devised for recitation out loud and not for reading to oneself, they were nonetheless written in an archaizing language quite distinct from daily speech. ${ }^{96}$ That is to say, the difference between elite and popular literature pivoted on their linguistic features, and did not lie in the rhetorical devices typical of Greek literature. Their orality was functional, not the legacy of an imaginary popular prehistory. ${ }^{97}$

\footnotetext{
${ }^{94}$ Morgan 2007, 4-5.
}

${ }^{95}$ Lloyd (2003) analyzes this difference as grounded in the respective hierarchical layout of the institutions in which knowledge (and hence texts) were created and transmitted.

${ }^{96}$ Tait 1996, 183. This was already true in the Middle Kingdom Period. See, for instance, Miriam Lichtheim's introduction to The Tale of the Shipwrecked Sailor $(1973,211)$.

${ }^{97}$ The depreciation of the indigenous literatures in Egypt, Judea (and Mesopotamia) derives from their being evaluated according to the codes of Greek literature, because their literary sophistication hinged on totally different devices. Irony and questions about the meaning 
The second reason to question the link between popular origin and the formal aspects noted above is that texts, not to mention stories circulating in oral form, are eminently malleable. This means that if the Judean literati who combined them with learned and priestly material had been troubled by their apparently frivolous tone and historical inaccuracies, there was nothing to prevent them from excising the compromising details and rectifying inaccuracies. The fact that they did no such thing suggests that there is more than meets the eye, and that we should look for additional or alternative explanations, beyond the popular story tag.

In this section I will discuss the notations that most modern scholars consider to be historical inaccuracies, and the use of generic terms. Consistent with my claim that the literati who composed the Judean narrative works in Judea and beyond were actually receptive to multiple influences, I argue that instead of being remnants of orality, these elements testify to different systems of memorializing the past that the Jewish authors, strikingly enough, had no qualms combining, even within a single work.

What is at stake here is the definition of the boundary between 'truth' and 'fiction', or between 'true' and 'untrue' narratives, concepts that modern scholars apply when analyzing the relationship between (Greek) historiography and the novel. In particular, Sara Johnson has pointed to a number of works composed in Hellenistic times that in her view, 'do not aim to tell the truth' ${ }^{98}$ Accordingly, she proposes a category of 'historical fictions', which she asserts offer a 'deliberate misrepresentation of history'. ${ }^{99}$ Unfortunately, Johnson's angle of inquiry overlooks various fundamental studies on Greco-Roman historiography that underline the difference between untruth and outright fiction, and acknowledge the coexistence of different kinds of 'history' (e.g., 'intentional history'). ${ }^{100}$ Aristotle's derogatory assessment of Greek historia as opposed to tragedy may be worth remembering in this respect (Poetics, 9,1451a37-b38). Secondly, Johnson's approach equates 'history' itself with the elite Greek conception thereof, and as we saw above, although the Jewish authors of Hellenistic times were familiar with Herodotus' and Hellenistic historiography, beyond the tools offered by the dominant, Greek culture, they experimented multiple ways of exploring their past and

of historical events were communicated by implication. For Hellenistic works, see Wills 1990, 44. For Chronicles in Judea (late fourth century) and Babylonia (Seleukid times), see Ben Zvi 2006, 20; Waerzeggers (forthcoming). Statements in wisdom literature which are wrongly read as prescriptive are actually cognitive prototypes aimed to inform the readers' mora imagination and help them evaluate real-life situations. See Stewart 2016.

${ }^{98}$ S. Johnson 2004, 3. See also Wills 2011, 147-148.

${ }^{99}$ S. Johnson 2004, 11.

${ }^{100}$ On untruth vs. fiction, see Gill and Wiseman 1993; cf. Woodman 1988. On intentional history, see Foxhall and Luraghi 2010. 
constructing their collective identity, thereby continuing a long tradition of eclecticism.

\subsection{Historical inaccuracies}

Greek historia itemizes the past. Although Herodotus wrote about the Persian wars with Homer's Trojan war in mind, and Thucydides compared his own account of the Peloponnesian war with Herodotus' relation of events, the Greek tradition kept these three episodes neatly distinct. To some extent, the genre of chronicles that was widely diffuse from Mesopotamia through Judea to Egypt, also constructed time in a linear way. However, in the same way that in the Greek realm historia never evicted myth or tragedy, the societies of the ancient Near East cultivated various ways of memorializing the past. In Egypt, a well-documented technique consisted in conflating events that occurred at different periods, in order to better highlight their intrinsic thematic similarities. ${ }^{101}$

Underpinning this conception of history was the founding myth of the king's daily fight for ensuring the maintenance of $M a^{\prime} t$ (truth, justice, and order) over the constant assaults of Isfet (lie, wrongfulness, and chaos). ${ }^{102}$ In historical time, 'chaos' could take the form of a foreign invasion, a domestic rebellion, or palace intrigues. ${ }^{103}$ Within these categories, all the specific episodes related had the same basic meaning, and instead of individualizing each event as Greek historia did, the past was thematized for the sake of intelligibility. That is to say, it was divided not according to the succession of dynasties but into set topical categories, such as 'the foreign king who invaded the country'. As a result, all foreign conquerors falling under this thematic label were conveniently conflated to consolidate the category in question. The Inaros Epic is a good case in point. ${ }^{104}$ The eponym hero ruled Athribis when the Assyrian king Esarhaddon invaded Egypt, but one of the main episodes in the cycle is the conflict between king Necho of Egypt and king Esarhaddon of Assyria. However, in (modern) historical terms Necho rebelled against Assurbanipal, Esarhaddon's son. ${ }^{105}$ Even more remarkably, the Assyrian

${ }^{101}$ For the cultural (and religious) background to the late Egyptian handling of the past, see Gozzoli 2006.

102 The basic work on this subject is Hornung 1966. See also Gozzoli 2006. For a summary, see Dieleman and Moyer 2010, 435-436.

${ }^{103}$ As noted by Ann-Kristin Wigand in 'Remembering Assyria or Reflecting Something Else? Some Common Features in Aramaic and Egyptian Courtier Tales', a paper she delivered at the EABS Annual Conference, Berlin August 8, 2017.

104 Ryholt 2004, 491-492.

${ }^{105}$ Ibid.: 492. 
king revered Atar, the Persian god of fire and son of Ahura Mazda. ${ }^{106}$ Rather than inadvertent errors, these conflations signal a genre of history-writing that was concerned less with chronology than with pinpointing recurrent patterns in human history. Basically, they were a tool of historical interpretation.

In my view, the transformation in Judith of the figure of Nebuchadnezzar into the 'king of the Assyrians' invading Judea after the exile is a clear indicator of Jewish authors endorsing Demotic thematic history, and the same is true with other 'historical errors' that keep modern commentators perplex. While in Judea the original cultural underpinnings of this conception of history were forgotten, its formal feature was adopted with a new meaning. As noted in Genesis Rabba $(16,4)$ :

Rabbi Huna in the name of Aha said: 'All empires may be called Assyria, because they extract wealth out of Israel'. Said Rabbi Yossi son of Hanina: 'All empires may be called Nineveh, because they adorn themselves at the expense of Israel'. Said Rabbi Yossi son of Rabbi Halafta: 'All empires may be called Egypt, because they oppress Israel'.

\subsection{Generic Names}

Altogether, modern scholars have identified multiple hints to the influence of various royal ideologies in the Judean stories of Hellenistic times. ${ }^{107}$ By the same token, it is worth reconsidering the formal framework of Judean stories, which arguably most resembles the modern European folktales studied by Propp and the ATU classification system, namely the use of generic names or terms, such as 'the king'. While the elite notion of history in Egypt conflated events belonging to a similar conceptual category (such as 'foreign invasion'), the Persian royal inscriptions tended toward abstraction. Darius I's early inscriptions record the name of the enemy kings and people that he vanquished, but these particularizing details are omitted in his later inscriptions, a practice continued by Darius' successors. ${ }^{108}$ In terms of royal ideology, its rhetorical effect is indeed powerful, as the narrative focuses on the essential matter - the king as restorer of truth and order over the lie and disruption of his enemies - from which details distract attention.

${ }^{106}$ Ibid.: 494. See also Ann-Kristin Wigand, "Remembering Assyria or Reflecting Something Else? Some Common Features in Aramaic and Egyptian Courtier Tales," paper presented at the EABS Annual Conference in Berlin, 8.8 2017.

107 On allusions to Assyrian royal ideology in Esther, see above, n. 74.

${ }^{108}$ Sancisi-Weerdenburg 1999. The Behistun inscription displays the two systems, illustrating the transition. See Root 1979, 186-190. 
While this interpretation remains speculative, I suggest that texts such as the account of the king's persecution of the Judeans in 1 Macc 1,41-64 (or the Story of the Mother and her Seven Sons in 2 Macc. 7) offer parallels of the characteristic Persian abstract view of history. In 1 Maccabees, readers readily identify 'the king' as Antiochus IV thanks to the narrative context in which the persecution account is inserted, but within the narrative unit itself, he is not named.

\subsection{Ancient Receptions: From Herodotus to Josephus}

One further argument challenges the view that the Judean stories in their final form (not their genesis) were intended as 'pure entertainment', and that is their reception in ancient times. As I argued in section 2.1 above, the fact that 25 percent of the works composing the temple library in Tebtunis qualify as 'narratives' rules out that this form of literature was merely recreational. Furthermore, papyrological evidence attests that in Egypt, short stories were used as school exercises for the training of scribes. ${ }^{109}$ This would put these texts on a par with sapiential texts, which as far as we know were also used in the early stages of scribe training. 110

Next, we may adduce the evidence of ancient authors. The stories of Pharaohs Sesostris and Pheros that Herodotus cites in his history of Egypt (2,102-110 and 2,111, see also Diodorus Siculus 1,59 and Pliny the Elder, $N H 36,74$ ) feature in the Petese story sequence that belonged to the Tebtunis library. ${ }^{111}$ Likewise, knowledge of the Inaros-Petubastis cycle has been thought to be reflected in the account of Inaros' rebellion against Artaxerxes I in Thucydides (1,104, 109-110). The fact that Herodotus (and Thucydides) quoted Babylonian and Egyptian narratives in their historiai is evidence that they held pieces of story-telling as reliable sources for inquiring into the past, particularly since it has been established that Herodotus used stories (labeled as 'anecdotes' in Herodotean scholarship) to construct historical meaning. ${ }^{112}$ Likewise, the history of Egypt that Manetho wrote in Greek for one of the first Ptolemies shares affinities with the Demotic narratives memorializing the heroes of pharaonic Egypt. ${ }^{113}$

A similar argument may be applied to Josephus' reception of earlier Judaean stories in the first eleven books of his Antiquities and in Against Apion. For instance, in his account of Persian times in Antiquities 11,1-158, Josephus included

109 On Egypt, see Tassier 1992; Ryholt 1998; and 2010. On Hebrew narratives fulfilling a similar function, see Davies 1998, 150-151.

${ }^{110}$ Carr 2005.

111 Widmer 2002; Dieleman and Moyer 2010, 436.

112 Griffiths 2006.

${ }^{113}$ Dieleman and Moyer 2010, 436. 
Esther $(A J 11,33-58)$ on an equal footing with the Ezra document. Modern scholars have been primarily interested in analyzing how Josephus modified his sources. ${ }^{114}$ However, it is significant that he considered these stories to be suitable material for a historian to use. ${ }^{115}$ More accurately, in his methodological statement included in the Proem to Antiquities, Josephus asserts the superiority of his sources over those of Greek historians, because his were 'sacred scriptures' (hiera grammata) containing 'the history (historia) of five thousand years' of the Judeans $(A J 1,13-14)$. If at all, then, his sources were more reliable than those of Dionysius Halicarnassus. ${ }^{116}$

Granted all this, the most telling aspect in the reception of the narrative material concerns their earliest phase of development: whatever the original form of the Judean stories, some literati found it appropriate to combine them with priestly material. This was the case in MT Daniel, in which a series of 'court tales' are combined with apocalyptic visions, and LXX 1 Esdras, in which the Story of the Three Guards $(3,1-5,6)$ was interwoven with an Ezra text. As far as I am aware, no modern scholar has ventured to explain why literati would have used literature destined for recreational occasions to compose texts of a priestly nature. Ultimately, the evidence about the early reception of stories is corroborated by a more theoretical look at the respective status of 'entertainment' and 'fiction' in Judea (and Egypt) in Hellenistic and Roman times.

\section{Judean Stories as Tools of Exploring Knowledge}

To summarize my discussion thus far, the biblical narratives of Hellenistic times interpreted the recent past as enactments of divine salvation, and to make them more readable they transposed the said events into fanciful settings and deployed a broad palette of methods for addressing the past, contrived from (at least) four different traditions: indigenous Deuteronomic history; Greek historia; Egyptian conflations; and Persian generic abstractions.

In the wake of the pioneering studies of the 1960s conducted by Shemaryahu Talmon and Gerhard von Rad, various scholars continue to stress the connections between Jewish court tales (Daniel 1-6; Esther) and sapiential literature. ${ }^{117}$ Wisdom as a genre served as a means to instruct and enculture young minds into the

\footnotetext{
${ }^{114}$ Feldman 1989.

115 See Antiquities 1.14 (historia) and 18 (praxeis).

${ }^{116}$ As Steve Mason pointed out to me, 'Josephus boasts that Judaeans know the past, where it really counts, in ways that are better or safer than historia - from prophets' (personal communication, October 14, 2018).

117 Talmon 1963; von Rad 1966, cited in Wills 1990, 23-38, 43; Murphy 2002.
} 
basic values of a given society, and at the same time impart models of ideal behavior (and archetypal vices). This task explains the key function of wisdom texts in educational curricula across the ancient Near East; furthermore, given that scribes served in the courts, court tales as a genre offered the most natural medium for narrativized wisdom. ${ }^{118}$ In light of my discussions in sections 2 and 3 above, in which I identified the biblical narratives as vehicles of religious and historical knowledge, the accepted view of biblical narrative literature as basically serving to educate the young fails to do justice to their more layered nature. Rather, like their Demotic counterparts, they provided a tool for exploring virtually all the aspects of knowledge that were of interest to their authors and audience. To recognize this, it is necessary first to examine the nature of fiction and what constituted literary pleasure in the ancient Mediterranean.

\subsection{Fiction as Entertaining and Educational}

Fiction defined as the self-referential narrative world of a story is a universal phenomenon. All human societies create "narratives that are accepted as not literally true but as vehicles for a kind of moral or cultural truth' ${ }^{119}$ However, the nature of the contract between the implied author and the ideal reader, that is, the nature and extent of the reader's willing suspension of disbelief, is culturally specific, and evolves with time within a society to accompany social changes. ${ }^{120}$ In the ancient Mediterranean, a remarkable window of autonomous fiction - that is, works in which fiction is an end per se-opened in Roman imperial times. However, it was restricted to a handful of works - the so-called imperial novelswhich, to judge from the scant number of extant manuscripts known for each one of them, enjoyed a very limited, and elitist, readership. ${ }^{121}$ For the overwhelming number of fictionalized texts, fiction was not an aim per se. In terms of function, it was not intended for mere entertainment, but was subordinated to the main purpose (or purposes) of the texts, which were educational. To judge by their popularity, biblical novelized narratives do not belong with the elitist imperial novels, but with the main category.

\footnotetext{
${ }^{118}$ On the educational purpose of wisdom literature, see Carr 2005.

119 On fiction in Hellenistic times, see Whitmarsh 2013, 11-23.

120 Whitmarsh 2013, 13-16.

${ }^{121}$ Selden 2010, 12, with n. 73.
} 
Fiction was a powerful means of spreading knowledge because of its emotional potential. For ancient Greek authors and literary theoreticians, 'pleasure' (terpsis) was vital to facilitate, and in truth, create communication with the audience, and hence to allow the text's message to reach through. ${ }^{122}$ With the notable exception of Thucydides, all Greek (and Roman) historians and orators cared to combine enjoyment with instruction ('usefulness'). In sum, Greek and ancient Near Eastern literary cultures were underpinned by quite different poetics, but agreed on this one issue: fiction and instruction are allies, not enemies. Parenthetically, amid the flurry of post-colonial theory in recent years, some scholars have sought to read subversion into biblical narratives, or flag them as 'resistance' literature. This angle of interpretation is not compelling. ${ }^{123}$ It is absolutely possible to attribute to the stories a more conformist function, in line with my claim that they can be seen as priestly literature.

The power of fiction for instilling wisdom, ethics, and knowledge has been discussed in numerous inquiries, both through case-studies and in theoretical analyses related to literary studies and cognitive linguistics on fiction and the ethical imagination. ${ }^{124}$ In a nutshell, the fictional aspects of the stories are secondary to the underlying didactic purpose of the text, and hence in methodological terms a new way of categorizing these works is in order. This issue requires in-depth inquiry, and the following discussion can only lay out milestones.

\subsection{Grouping Texts according to Categories of Knowledge}

As we saw in the introduction to this article, the principal rationale behind the discussion of these so-called 'biblical stories' is precisely their fictional quality. The moment this aspect is redefined as subordinate, we need to shift our attention to the categories of knowledge the stories attended to: for instance, wisdom, mantic tradition, prophecy, revealed knowledge (that is, apocalypticism), history, political, social, and religious matters, and not least law.

122 Morgan 2007, 1-22.

${ }^{123}$ I mean that Whitmarsh's emphasis on the genre's subversive potential should not be pursued too far (2013). Admittedly, the king is mocked as long as he relies on his non-Judean courtiers and does not acknowledge the God of Israel, but it is hard to believe that ancient Judean readers would have continued to mock the king after he acknowledged that his truly faithful servants are the Jewish courtiers, and confessed his faith in the God of Israel (Daniel 1-6; Esther; 3 Maccabees).

${ }^{124}$ See, for instance, M. Johnson 1993; Macintyre 2007; Austin 2011. For an application of these theories to the Book of Tobit, see Macatangay 2011, 115. 
Each category of knowledge was explored through a variety of discourses and literary forms, both narrative and non-narrative. For instance, wisdom is subdivided into sayings or instructions (such as Proverbs or Qohelet), dialogues (Job), and court stories (Esther, Daniel; cf. Ahiqar). ${ }^{125}$ These various modes of discourse could be combined - a device Demotic literature excelled in. In the Wisdom of Onchsheshonqy, a narrative framework bookends a series of instructions, and the difference between the two discursive forms was exploited to create an ironic contrast in content, as well. ${ }^{126}$ Following a plot against the king in which his friend and Pharaoh's chief physician Harsiesis is involved, Onchsheshonqy is thrown into jail far from home. Made wiser by his bitter experience, he sets to write down proverbs to ensure that his son does not follow in his footsteps. ${ }^{127}$ Setting irony aside, the Book of Tobit endorses the literary structure of the Demotic type, as the fatherly instructions are inserted within a didactic story of travel (Tob 1-3 and 13-14). Indeed, the biblical prophetic books subscribe to a similar template. Like wisdom, prophecy is subdivided into oracular responses and biographical narratives, and in the prophetic books the two are systematically interleaved, the biography of the prophet framing the prophecies that were attributed to him.

History was explored through multiple narrative forms, including the Pentateuch, Judges, Kings, Chronicles, complex prophetic books, the Qumran Pesharim, and numerous self-contained stories running the gamut from prophetic books again, through Ezra-Nehemiah and LXX 1 Esdras to Esther, Judith, and 1 and 2 Maccabees. As we saw above, stories also deployed diverse conceptions of history.

Because priests had access to the most sacred areas of the temple courts, they submitted themselves to strict rules of purity. For reasons that remain disputed, in the third and second centuries BCE, the issue of priestly genealogy became a bone of contention among temple families. The debate about marriage regulationsthat is, what class of woman was permitted to wed a priest - was raised in a wide array of texts. Expectedly, the argument is central to the Testament of Levi (one of the Testaments of the Twelve Patriarchs), given that Levi, the third son of Jacob and Leah, was the ancestor of all the priests. The theme also recurs in the Wisdom of Ben Sira; the account of Antiochus IV's religious persecution in 2 Maccabees $(6,4)$; and even in the late Psalms of Solomon $(2: 11,13)$.

${ }^{125}$ For the link between court tales and wisdom, see Murphy 2002; Macatangay 2011. For parallels to these formal features in Demotic literature, see Quack 2009, 111-173.

126 Tait 1996, 185; Quack 2009, 128-130.

${ }^{127}$ See Wills 1990, 43. Contrary to what Wills implies, this kind of contrapuntal irony was traditional in Egyptian literature. See above, n. 50. 
Furthermore, as Devorah Dimant has claimed, the issue of priestly genealogy forms a common thread through a cluster of Aramaic manuscripts found in Qumran, which stand apart because of their language - the overwhelming majority of the Qumran library was in Hebrew. This Aramaic corpus includes the Aramaic Testament of Levi (4QTLevi $\left.{ }^{\text {a }} 1,13\right)$; the Genesis Apocryphon; and two narrative works, namely the Aramaic fragments of the Book of Tobit related to Greek Tobit preserved in the Septuagint; and the Aramaic fragments of the Book of Watchers, which antedate the Ge'ez translation preserved in 1 Enoch 1-36. Pointing to these linguistic and thematic affinities, Dimant (in my view cogently) argued that Greek Tobit was also related to this group of texts. ${ }^{128}$

The main plot in Tobit consists in the initiatory journey of Tobias, Tobit's son, to visit his relative Sarah, by the end of which Tobias brings back a remedy to cure his father's blindness and Sarah as a bride for himself. The theme of marriage has earned Tobit a place in Wills' list of Jewish 'ideal novellas', but, as with Esther and Judith, this characterization begs the question of how and why the work was eventually included in the Septuagint. Whereas Dimant's reclassification of the theme as related to priestly genealogy provides a simple explanation. Furthermore, Tobias' endogamous marriage - referencing the stories of the patriarchs in Genesis - presumably appealed to diaspora communities, explaining why the Greek recension was canonized. ${ }^{129}$ To my mind the connections with the Greek romantic novel remain tenuous.

The Jewish short stories of Hellenistic times were ideally suited to thematize contemporary religious innovations. While the first temple built in the days of the native monarchy benefited from the king's economic support, the temple that was rebuilt in Jerusalem in the Achaemenid era reinvented itself as the focus of popular piety. As a result, purity rites - traditionally the purview of the priests serving at the sacrificial altar - spread to the wider Jewish population. At the same time, the exclusive centralization of the sacrificial rites in Jerusalem prompted the emergence of new forms of piety (food taboos; prayer; and bathing rites) whose shared function was to maintain (or invent afresh) the religious and emotional ties between Judeans around the Mediterranean and the Jerusalem temple. We may reasonably presume that this novel religious organization prompted the need for new didactic texts, and fictionalized narratives were particularly suited for this purpose. ${ }^{130}$ It also explains why such texts were needed in Greek versions. Greek

${ }^{128}$ Dimant 2017a; 2017b.

${ }^{129}$ Dimant 2017c, 228. Both Isaac and Jacob marry relatives (Gen 24,47-48; 29,10-12).

130 This definition admittedly comes close to Wills', but I insist on the primarily didactic function of these texts. Moreover, as noted above (section 2.3), we cannot infer from their style that they broke free of the institutional setting. 
Esther, Judith, and Tobit are often described as praying, while food taboos are a prominent aspect of the plots in Judith and Daniel 1-6, which also tackle the question of how to keep these rules of piety in a foreign environment.

The list of topics just surveyed is far from exhaustive. Political, social, and religious matters such as the need to rebuild the temple, the relationship between empire and the local community, the question of exile, and the importance of having Judean courtiers close to the king were explored in prophetic works (Haggai, Zechariah) and short stories, particularly but not only court tales (Esther, Tobit). Moreover, Tobit explores the theme of the suffering of the righteous (like Job), and its retributive theology has been compared variously with so-called Deuteronomic theology and with such Hellenistic works as Ben Sira and 1 Enoch. ${ }^{131}$ Finally, Tobit includes lore related to demons and angels.

Inevitably, the boundaries between these categories of knowledge are fluid, and stories typically accommodate multiple themes in a sort of mix-and-match: life is a multifaceted business, and, as noted above, fiction is particularly apt to capture this complexity, all the more since the literary form of story-telling is eminently adaptable and largely eludes the strictures of form.

The comparison with Demotic narratives also casts light on the absence of certain themes and categories of lore: while magic is pervasive in Egyptian texts, it is marginal in Judean stories, with the exception of Daniel and Tobit. This disparity between Demotic and Judean texts shows that themes and literary features were not borrowed indiscriminately, but were carefully screened for their cultural pertinence for the borrowing society (in this case, the Judean one), a fact that further buttresses the assertion that stories were not merely glib entertainment but serious tools to foster exploration and knowledge in their audience.

It has been argued that Plato's Atlantis myth in the Timaeus-Critias dialogue was a narrative experiment demonstrating how Athenians raised according to Plato's theoretical layout of the ideal politeia in the Republic would fare in wartime. ${ }^{132}$ A high proportion of Demotic narrative stories illustrate the deeds of prominent magicians of old, a kind of lore that was highly praised in Egyptsome of these magicians were revered through cults in Hellenistic times. ${ }^{133}$ In my view, biblical narratives belong with these texts, rather than with the Greek novel.

\footnotetext{
${ }^{131}$ Spencer 1999, 159-160. Ben Sira and 1 Enoch: Kiel 2012.

132 Johansen 2004.

${ }^{133}$ For a survey of the extant texts true to 1999, see Ryholt 1999, 83. For the cult of Imhotep/Imouthes, the architect of Pharaoh Djoser of the third dynasty (ca. 2670-2650 BCE) and builder of his celebrated pyramid, see Thompson 2012, 19-22, 194-96.
} 


\section{Novelization and Urbanization: A Concluding Note}

The social and cultural changes that accompanied the emergence of novelistic literature in the ancient Mediterranean is a fascinating issue, but also a vexed matter. Its indigenous development within the Greek realm is complex enough, but the question I raised in the foregoing article is whether its encounter with other traditions such as the Demotic and the Judean/Jewish could only occur in the Greekspeaking urban centers of the Eastern Mediterranean that thrived after Alexander's conquest. To round up this article, I wish to propose a nuanced answer.

Biblical narratives of Hellenistic times are a privileged source of evidence to address this issue for two interrelated reasons. The centralization of the sacrificial cult in the Jerusalem temple entailed the development of new religious practices within the Jewish populations for whom these texts were produced, and the Jewish populations lived in two basic kinds of social, cultural, and linguistic environments, namely Judea on the one hand, and Greek-speaking areas on the other, in particular Egypt. Moreover, the Jewish populations that settled outside Judea frequently clustered in organized communities which genuinely developed a relationship of diaspora vis-à-vis Jerusalem, whereby the local cultic centralization also became an imaginary, emotional link to that remote religious center. ${ }^{134}$ When we consider the Jewish literary production of the period this diasporic situation creates an interesting sub-category of rhizomatic 'text network' as theorized by Daniel Selden, whereby texts and ideas circulated across geographical and cultural (Greek vs. Judean) boundaries while delineating a coherent religious and cultural ('Jewish') space. The Jerusalem scribes linked to the temple and/or the Hasmonean/Herodian court were influenced not only by Greek Alexandrian authors (such as historians and playwrights) and Egyptian scribes, but also by Jewish Alexandrian writers, who would have mediated the reception of Greek and Demotic literature in Jerusalem in one way or another. ${ }^{135}$

It may be this bi- or multi-directional relationship rather than the development of Jewish urbanites that explains the literary genesis of Judith and Greek Estherin my view, the only two biblical works meeting Lawrence Wills' criteria of the ideal novella. At the same time, as stated above, the colophon of OG Esther emphasizes that the man who brought the text to Egypt was 'a priest and a Levite', a datum that links the text with the temple institution in Jerusalem. In sum,

\footnotetext{
${ }^{134}$ On the cult centralization, see Rhyder 2019.

${ }^{135}$ Selden 2010.
} 
individual eroticism runs rife while being kept firmly under control through its carnivalization. ${ }^{136}$

\section{Bibliography}

Agut-Labordère, D., and Chauveau M. (edd). 2011. Héros, magiciens et sages oubliés de l'Égypte ancienne: une anthologie de la littérature en égyptien démotique, Paris: Les Belles Lettres.

Austin, M. 2011. Useful Fictions: Evolution, Anxiety, and the Origins of Literature, Lincoln, Neb: University of Nebraska Press.

Bakhtin, M. 1984. Rabelais and his World. Bloomington, IN: Indiana University Press.

Ben Zvi, E. 2006. History, Literature and Theology in the Book of Chronicles, London - Oakville: Equinox.

Berlin, A. 2001. 'The Book of Esther and Ancient Storytelling', JBL 120, 3-14.

Bezold, H. Forthcoming. 'Violence and Empire: Hasmonean Perspectives on Imperial Power and Collective Violence in the Book of Esther', in J. Rhyder and S. Amman, Memorializing Collective Violence in Judean Narrative Traditions. Hebrew Bible and Ancient Israel.

Bringmann, K. 1983. Hellenistische Reform und Religionsverfolgung in Judäa: Eine Untersuchung zur jüdisch-hellenistischen Geschichte (175-163 v.Chr.), Göttingen: Vandenhoeck und Ruprecht.

Caponigro, M.S. 1992. 'Judith, Holding the Tale of Herodotus', in J.C. VanderKam (ed.), 'No One Spoke Ill of Her': Essays on Judith, Atlanta, Ga: Scholars Press, 47-59.

Carr, D.M. 2005. Writing on the Tablet of the Heart. Origins of Scripture and Literature, Oxford: Oxford University Press.

Chaniotis. A. 2013. 'Empathy, Emotional Display, Theatricality, and Illusion in Hellenistic Historiography', in A. Chaniotis and P. Ducrey (edd.), Unveiling Emotions II: Emotions in Greece and Rome: Texts, Images, Material Culture, Stuttgart: Franz Steiner, 53-84.

Clarysse, W., and D.J. Thompson. 2006. Counting the people in Hellenistic Egypt, Vol. 2: Historical Studies. Cambridge: Cambridge University Press.

Craig, K.M. 1995. Reading Esther: A Case for the Literary Carnivalesque, Louisville, Ky: Westminster John Knox.

Dalley, S. 2007. Esther's Revenge at Susa: From Sennacherib to Ahasuerus, Oxford: Oxford University Press.

Davies, P.R. 1998. Scribes and Schools: The Canonization of the Hebrew Scriptures, Louisville, Ky: Westminster John Knox.

Depauw, M. 1997. A Companion to Demotic Studies, Brussels: Fondation Égyptologique Reine Élizabeth.

Dieleman, J., and I.S. Moyer 2010. 'Egyptian Literature', in James J. Clauss and Martine Cuypers (edd), A Companion to Hellenistic Literature, Malden, Oxford, and Chichester: Wiley-Blackwell, 429-447.

Dimant, D. 2017a. 'Tobit and the Qumran Aramaic Texts', in D. Dimant From Enoch to Tobit: Collected Studies in Ancient Jewish Literature, Tübingen: Mohr Siebeck, 173-92.

Dimant, D. 2017b. 'The Book of Tobit and the Qumran Halakhah', ibid., 193-212.

${ }^{136}$ I wish to thank Lawrence Wills for his thoughtful comments on a previous version of this article. The present text is, of course, my sole responsibility. 
Dimant, D. 2017c. 'The Family of Tobit', ibid., 223-228.

Doran, R. 1986. 'Narrative Literature', in R.A. Kraft and G.W.E. Nickelsburg (edd.), Early Judaism and its Modern Interpreters, Philadelphia, Penn: Fortress Press, 287-310.

Eckhardt, B. 2009. 'Reclaiming Tradition: The Book of Judith and Hasmonean Politics', Journal for the Study of the Psedepigrapha 18, 243-263.

Esler, P.F. 2002. 'Ludic History in the Book of Judith: The Reinvention of Israelite Identity?', Biblical Interpretation 10, 107-143.

Feldman, L.H. 1989. Studies in Josephus' Rewritten Bible, Leiden: Brill.

Foxhall, L., and N. Luraghi. 2010. 'Introduction', in L. Foxhall, H.-J. Gehrke, and N. Luraghi (edd), Intentional History. Spinning Time in Ancient Greece, Stuttgart: Steiner, 9-14.

Gera, D.L. 2014. Judith: Introduction, Translation and Commentary, Berlin - Boston: de Gruyter.

Gill, C, and Wiseman, T.P. (edd.). 1993. Lies and Fiction in the Ancient World, Austin: University of Texas Press.

Gorre, G. 2009. Les Relations du clergé égyptien et des Lagides. Studia Hellenistica 43. Leuven: Peeters.

Gozzoli, R.B. 2006. The Writing of History in ancient Egypt during the First Millennium BC (ca. 1070-180 BC). Trends and Perspectives, London: Golden House.

Griffiths, A. 2001. 'Kissing Cousins: Some Curious Cases of Adjacent Material in Herodotus', in N. Luraghi (ed.), The Historian's Craft in the Age of Herodotus, Oxford: Oxford University Press, $161-178$.

Griffiths, A. 2006. 'Stories and Storytelling in the Histories," in C. Dewald and J. Marincola (edd), The Cambridge Companion to Herodotus, Cambridge: Cambridge University Press, 130-144.

Gruen, E.S. 1997. 'Fact and Fiction: Jewish Legends in a Hellenistic Context,” In P. Cartledge, P. Garnsey, and E. Gruen (edd), Hellenistic Constructs: Essays in Culture, History, and Historiography, Berkeley: University of California Press, 72-104.

Gruen, E.S. 1998. Heritage and Hellenism, Berkeley: University of California Press.

Gruen, E.S. 2016. The Construct of Identity in Hellenistic Judaism: Essays on Early Jewish Literature and History, Berlin: de Gruyter.

Gutzwiller, K. 2007. A Guide to Hellenistic Literature, Malden, MA - Oxford - Carlton: Blackwell.

Hengel, M. 1969. Judaism and Hellenism: Studies in their Encounter in Palestine during the Early Hellenistic Period. London: SCM Press.

Hoffmann, F. 1996. Der Kampf um den Panzer des Inaros. Vienna: Brüder Hollinek.

Hoffmann, F., and J.F. Quack. 2007. Anthologie der demotischen Literature, Münster: LIT.

Holm, T.L. 2013. Of Courtiers and Kings: The Biblical Daniel Narratives and Ancient StoryCollections, Winona Lake, IN: Eisenbrauns.

Honigman, Sylvie. 2014. Tales of High Priests and Taxes: The Books of the Maccabees and the Judean Rebellion Against Antiochus $I V$, Berkeley: University of California Press.

Honigman, Sylvie. 2016. "Intercultural Exchanges in the Hellenistic East: The Respective Roles of Temples, Royal Administrative Offices, Royal Courts, and Gymnasia." In Centres and Peripheries in the Early Second Temple Period, edited by E. Ben Zvi and C. Levin, 49-78. FAT. Tübingen: Mohr Siebeck

Honigman, S. Forthcoming1. 'Introduction', in S. Honigman, C. Nihan, and O. Lipschits (edd), Times of Transition: Judea in the Early Hellenistic Period, Philadelphia - Winona Lake, IN - Tel Aviv: Penn State University, 1-15. 
Honigman, S. Forthcoming2. 'Between the Temple and Royal Administrations: The Social Location of Literate Judean Elites in Early Hellenistic Times', ibid., 199-228.

Honigman, S. Forthcoming3. 'Commemorative Fictions: Athens (480 BCE), Jerusalem (168 $\mathrm{BCE}$ ), and Alexandria (38 CE),' in J. Rhyder and S. Amman, Memorializing Collective Violence in Judean Narrative Traditions. Hebrew Bible and Ancient Israel.

Honigman, S. Forthcoming4. "Social and Economic Upheavals and the "De-Traditionalization" of Judean Society in Hellenistic Times: The Background to Sectarianism', in M. Bar-Asher Siegal and J. Ben-Dov. (edd.), Social History of the Jews in Antiquity: Studies in Dialogue with Albert Baumgarten's Work. Tübingen: Mohr Siebeck.

Hornung, E. 1966. Geschichte als Fest: Zwei Vorträge zum Geschichtsbild der frühen Menschheit, Darmstadt: Wissenschaftliche Buchgesellschaft.

Humphreys, L.W. 1973. 'A Life-Style for Diaspora: A Study of the Tales of Esther and Daniel', JBL 92, 211-223.

Johansen, T.K. 2004. Plato's Natural Philosophy. A Study of the Timaeus-Critias, Cambridge: Cambridge University Press.

Johnson, Mark. 1993. Moral Imagination: Implications of Cognitive Science for Ethics, Chicago: University of Chicago Press.

Johnson, S.R. 2004. Historical Fictions and Hellenistic Jewish Identity: Third Maccabees in its Cultural Context, Berkeley: University of California Press.

Johnson, S.R., R.R. Dupertuis, and C. Shea (edd). 2018. Reading and Teaching Ancient Fiction: Jewish, Christian, and Greco-Roman Narratives, Atlanta: SBL Press.

Kiel, M.D. 2012. The 'Whole Truth': Rethinking Retribution in the Book of Tobit, London New York: T\&T Clark.

Krüger, T. 2004. Qoheleth, Minneapolis: Fortress Press.

Krüger, T. 2007. 'Did Job Repent? in T. Krüger et al. (edd.), Das Buch Hiob und seine Interpretationen, Zürich: Theologischer Verlag Zürich, 217-229.

Lacocque, A. 2007. Esther Regina: A Bakhtinian Reading, Evanston, Ill.: Northwestern University Press.

Lichtheim, M. 1973. Ancient Egyptian Literature: A Book of Readings. Vol. 1: The Old and Middle Kingdoms, Berkeley: University of California Press.

Lichtheim, M. 1980. Ancient Egyptian Literature: A Book of Reading, vol. 3: The Late Period. Berkeley: University of California Press.

Lipschits, O. 2011. 'Jerusalem between Two Periods of Greatness: The Size and Status of the City in the Babylonian, Persian and Early Hellenistic Periods', in L.L. Grabbe and O. Lipschits (edd), Judah between East and West: The Transition from Persian to Greek Rule (ca. 400-200 BCE), London - New York: T\&T Clark, 163-175.

Lloyd, G 2003. 'Literacy in Greek and Chinese Science: Some Comparative Issues', in H. Yunis (ed.), Written Texts and the Rise of Literature Culture, Cambridge: Cambridge University Press, 122-138.

Macatangay, F.M. 2011. The Wisdom Instructions in the Book of Tobit, Berlin: de Gruyter.

Macchi, J.-D. 2018. Esther, Stuttgart: Kohlhammer.

Macintyre, A. 2007. After Virtue: A Study in Moral Theory, third edition, Notre Dame, IN: University of Notre Dame Press.

Milne, P.J. 1988. Vladimir Propp and the Study of Structure in Hebrew Biblical Narrative, Sheffield: Sheffield Academic Press.

Morgan, T. 2007. Popular Morality in the Early Roman Empire, Cambridge: Cambridge University Press. 
Murphy, R. 2002. Wisdom Literature, Job, Proverbs, Ruth, Ecclesiastes, and Esther, Grand Rapids, Michigan: Eerdmans.

Newsom, C.A. 2002. 'The Book of Job as Polyphonic Text', JSOT 97, 87-108.

Newsom, C.A. 2003. The Book of Job: A Contest of Moral Imaginations. Oxford: Oxford University Press.

Niditch, S. 1987. A Prelude to Biblical Folklore: Underdogs and Tricksters, San Francisco: Harper and Row.

Niditch, S, and R. Doran. 1977. 'The Success Story of the Wise Courtier: A Formal Approach', JBL 96, 179-193.

Nickelsburg, G.W.E. 1984. 'Stories of Biblical and Early Post-Biblical Times', in M. Stone (ed.), Jewish Writings of the Second Temple Period, Assen: van Gorcum; Philadelphia: Fortress, 33-87.

Ogden, D. 2017. The Legend of Seleucus: Kingship, Narrative and Mythmaking in the Ancient World, Cambridge - New York: Cambridge University Press.

Parkinson, R.B. 2002. Poetry and Culture in Middle Kingdom Egypt. A Dark Side to Perfection, London - New York: Continuum.

Pury, A. de, Macchi, J.-D., and Römer, T. (edd.). 2000. Israel Constructs Its History: Deuteronomistic Historiography in Recent Research, Sheffield: Sheffield University Press.

Quack, J.F. 2009. Einführung in die altägyptische Literaturgeschichte III: Die demotische und gräko-ägyptische Literatur, second edition, Münster: LIT.

Rhyder, J. 2019. Centralizing the Cult: The Holiness Legislation in Leviticus 17-26, Tübingen: Mohr Siebeck.

Root, M.C. 1979. The King and Kingship in Achaemenid Art: Essays on the Creation of an Iconography of Empire, Leiden: Brill.

Rutherford, I.C. 1997. 'Kalasiris and Setne Khaemwas: Greek Novels and Egyptian Models', ZPE 117, 203-209.

Rutherford, I. 2013. 'Greek Fiction and Egyptian Fiction: are they related, and, if so, how?', in: T. Whitmarsh and Stuart Thomson (edd.), The Romance between Greece and the East, Cambridge - New York: Cambridge University Press, 23-37.

Rutherford, I. 2016. 'The Earliest Cross-Cultural Reception of Homer? The Inaros Narratives of Greco-Roman Egypt,' in idem (ed.), Greco-Roman Interactions: Literature, Translation, and Culture, 500 BCE-300 CE, Oxford: Oxford Classical Press, 88-106.

Ryholt, K. 1998. 'A Demotic version of Nectanebo's dream (P. Carlsberg 562)', ZPE 122, 197208.

Ryholt, K. 1999. The Story of Petese son of Petetum and Seventy Other Good and Bad Stories. Copenhagen: The Carsten Niebuhr Institute.

Ryholt, K. 2004. 'The Assyrian Invasion of Egypt in Egyptian Literary Tradition. A Survey of Narrative Source Material', in J.G. Dercksen (ed.), Assyria and Beyond. Studies Presented to Mogens Trolle Larsen, Leiden: Nederlands Instituut voor het Nabije Oosten, 483-510.

Ryholt, K. 2005. 'On the contents and nature of the Tebtunis Temple Library. A status report', in S. Lippert and M. Schentuleit (edd), Tebtynis und Soknopaiu Nesos: Leben im römerzeitlichen Fajum. Wiesbaden: Harrassowitz, 141-170.

Ryholt, K. 2010. 'A Sesostris Story in Demotic Egyptian and in Demotic School Exercises', in H. Knuf, C. Leitz, and D. von Recklinghausen (edd), Honi soit qui mal y pense. Studien zum pharaonischen, griechisch-römischen und spätantiken Ägypten zu Ehren von HeinzJosef Thissen, Leuven: Peeters, 429-437. 
Ryholt, K. 2013. 'Imitatio Alexandri in Egyptian Literary Tradition', in: T. Whitmarsh and Stuart Thomson (edd.), The Romance between Greece and the East, Cambridge - New York: Cambridge University Press, 59-78.

Ryholt, K. 2018. 'Scribal Habits at the Tebtunis Temple Library', in J. Cromwell and E. Grossman (edd), Scribal Repertoires in Egypt from the New Kingdom to the Early Islamic Period. Oxford: Oxford University Press, 153-183.

Sancisi-Weerdenburg, H. 1999. 'The Persian Kings and History', in C. Shuttleworth Kraus (ed.), The Limits of Historiography: Genre and Narrative in Ancient Historical Text, Leiden - Boston - Köln: Brill, 90-112.

Schmitz, B. 2015. 'The Function of the Speeches and Prayers in the Books of Judith', in A. Brenner-Idan (ed.), A Feminist Companion to Tobit and Judith, London: Bloomsbury, $164-174$.

Selden, D. 2010. 'Text Networks', Ancient Narrative 8, 1-24.

Soll, W. 1988. 'Tobit and Folklore Studies, with Emphasis on Propp's Morphology', in D.J. Lull (ed.), SBL Seminar Papers. Atlanta, Ga: Scholars Press, 39-53.

Spencer, R.A. 1999. 'The Book of Tobit in Recent Research', Currents in Research: Biblical Studies 7, 147-180.

Stewart, A.W. 2016. 'Wisdom's Imagination: Moral Reasoning and the Book of Proverbs', Journal for the Study of the Old Testament 40, 351-372.

Tait, W.J. 1994. 'Egyptian Fiction in Demotic and Greek', in J.R. Morgan and R. Stoneman (edd), Greek Fiction: The Greek Novel in Context, London - New York: Routledge, 203222.

Tait, W.J. 1996. 'Demotic Literature. Forms and Genres', in A. Loprieno (ed.), Ancient Egyptian Literature: History and Forms, Leiden - New York - Köln: Brill, 175-187.

Tait, W.J. 2012. 'Comparing Structures in the Greek Novel and Demotic Narrative', in P. Schubert (ed.), Actes du 26e Congrès international de papyrologie (Genève 2010), Geneva: Droz, 739-745.

Talmon, S. 1963. 'Wisdom in the Book of Esther', Vetus Testamentum 13, 419-455.

Tassier, E. 1992. 'Greek and Demotic School-Exercises', in J.H. Johnson (ed.), Life in a MultiCultural Society. Egypt from Cambyses to Constantine, Chicago: The Oriental Institute, 311-315.

Thompson, D.J. 2012. Memphis under the Ptolemies, Cambridge: Cambridge University Press.

Van Henten, J.W. 1995. 'Judith as Alternative Leader: A Rereading of Judith 7-13', in A. Brenner (ed.), A Feminist Companion to Esther, Judith and Susanna, Sheffield: Sheffield Academic Press, 224-252.

Van Minnen, P. 1998. 'Boorish or Bookish? Literature in Egyptian Villages in the Fayum in the Greco-Roman Period', Journal of Juristic Papyrology 28, 99-184.

Van Oppen de Ruiter, B.F. 2007. The Religious Identification of Ptolemaic Queens with Aphrodite, Demeter, Hathor and Isis, Unpublished Ph.D. dissertation, the City University of New York.

Vines, M.E. 2002. The Problem of Markan Genre: The Gospel of Mark and the Jewish Novel, Leiden - Boston: Brill.

Vinson, S. 2008. 'Through a Woman's Eyes, and in Woman's Voice: Ihweret as Focalizor in the First Tale of Setne Khaemwas', in P. McKechnie and P. Guillaume (edd), Ptolemy II Philadelphus and his World, Leiden - Boston: Brill, 303-351.

Vinson, S. 2016. 'Good and Bad Women in Egyptian and Greek Fiction', in I. Rutherford (ed.), Greco-Egyptian Interactions: Literature Translation, and Culture, 500 BCE-300 CE, Oxford: Oxford University Press, 245-266. 
Vinson, S. 2018. The Craft of a Good Scribe History, Narrative and Meaning in the First Tale of Setne Khaemwas, Leiden - Boston: Brill.

Von Rad, G. 1966. 'The Joseph Narrative and Ancient Wisdom', in idem, The Problem of the Hexateuch and Other Essays, trans. E.W. Trueman Dicken, New York: McGraw-Hill.

Waerzeggers, C. Forthcoming. 'Writing history under empire: The Babylonian Chronicle reconsidered', in M. Ossendrijver (ed.), Scholars, Priests and Temples: Babylonian and Egyptian Science in Context, Leuven: Peeters.

Whitmarsh, T. 2013. Beyond the Second Sophistic: Adventures in Greek Postclassicism, Berkeley: University of California Press.

Whitmarsh, T., and Thomson, S. (edd.). 2013. The Romance between Greece and the East, Cambridge: Cambridge University Press.

Widmer, G. 2002. 'Pharaoh Maâ-Rê, Pharaoh Amenemhat and Sesostris: Three Figures from Egypt's Past as Seen in Sources of the Greco-Roman Period', in K. Ryholt (ed.), Acts of the Seventh International Conference of Demotic Studies. Copenhagen, 23-27 August 1999, Copenhagen: The Carsten Niebuhr Institute, 377-394.

Wills, L.M. 1990. The Jew in the Court of the Foreign King: Ancient Jewish Court Legends, Minneapolis: Fortress.

Wills, L.M. 1994. 'The Jewish Novellas', in J.R. Morgan and R. Stoneman (edd.), Greek Fiction: The Greek Novel in Context, London: Routledge, 223-238.

Wills, L.M. 1995. The Jewish Novel in the Ancient World, Ithaca: Cornell University Press.

Wills, L.M. 2002. Ancient Jewish Novel: An Anthology, Oxford: Oxford University Press.

Wills, L.M. 2011. 'Jewish Novellas in a Greek and Roman Age: Fiction and Identity', Journal for the Study of Judaism 42, 141-165.

Woodman, A.J. 1988. Rhetoric in Classical Historiography. Four Studies, London: Croom Helm. 